\title{
CURRENT LITERATURE IN EXPERIMENTAL PSYCHOLOGY
}

\section{HUMAN EXPERIMENTAL PSYCHOLOGY}

England, J. L. (Brigham Young Univ., Provo, Utah $84601)$. Mathematical models of two-party negotiations. Behavioral Science, 1973, 18, 189-197.

Waag, W. L. (Nav. Aerosp. Med. Rsch. Lab., Pensacola, Fla. 32800), Tyler, D. M., \& Halcomb, C. G. Experimenter effects in monitoring performance. Bulletin of the Psychonomic Society, 1973, 1, 387-388.

\section{METHODS AND INSTRUMENTATION}

Clifton-Everest, I. M. (Exptl. Psychol. Lab., Cambridge, England). A simple technique for tracking visual fixations without restricting head movements. Behavior Research Methods \& Instrumentation, 1973, 5, 349-352.

Griesinger, D. W. (Inst. of Admin. \& Mgt., Union Coll., Schenectady, N.Y. 12308), \& Livingston, J. W., Jr. Toward a model of interpersonal motivation in experimental games. Behavioral Science, 1973, 18, $173-188$.

Hoddes, E. (Dept. of Psychiat., Stanford Univ. Sch. of Med., Stanford, Calif. 94305), Zarcone, V., Smythe, H., Phillips, R., \& Dement, W. C. Quantification of sleepiness: A new approach. Psychophysiology, 1973, 10, 431-436.

McGlynn, R. P. (Texas Tech Univ., Lubbock, Tex. 79409), \& Schick, C. Reduced information feedback on a selection concept learning task. Behavior Research Methods \& Instrumentation, 1973, 5 355-356.

Paulus, P. (Univ. of Texas at Arlington, Arlington, Tex. 76010), McCain, G., \& Cox, V. A note on the use of prisons as environments for investigation for crowding. Bulletin of the Psychonomic Society, 1973, 1, 427-428.

\section{Instrumentation and Techniques}

Coren, S. (New Sch. for Soc. Rsch., New York, N.Y. 10011), \& Miller, J. The use of photographic exposure meters as photometers. Behavior Research Methods \& Instrumentation, 1973, 5, 357-360.

Wallace, R. F. (Univ. of California, San Diego, La Jolla, Calif. 92100). A bifunctional pulse former. Journal of the Experimental Analysis of Behavior, 1973, 20, 28.

Statistical Techniques

Alf, E. F., \& Abrahams, N. M. (Nav. Pers. \& Trng. Rsch. Lab., Dept. of the Navy, San Diego, Calif. 92152). Reply to Edgington. Psychological Bulletin, 1973, 80, 86-87.

Caelli, T. M. (Univ. of Newcastle, Newcastle, New South Wales, 23081, Australia), \& Keats, J. A. An extended use of moments of two distribution functions for predicting performance in a pattern discrimination task. Journal of Experimental Psychology, 1973, 99, 209-214.

Edgington, E. S. (Univ. of Calgary, Calgary, Alta., Canada). The random-sampling assumption in "comment of component-randomization tests." Psychological Bulletin, 1973, 80, 84-85.

Gocka, E. F. (Western Rsch. Support Ctr., VA Hosp., Sepulveda, Calif. 91343). Regression analysis of proportional cell data. Psychological Bulletin, 1973, $80,25-27$
James, L. R. (Inst. of Behav. Rsch., Texas Christian Univ., Fort Worth, Tex. 76129). Criterion models and construct validity for criteria. Psychological Bulletin, $1973,80,75-83$.

Keselman, H. J. (Univ. of Manitoba, Winnipeg, Man., Canada), \& Toothaker, L. E. Error rates for multiple comparison methods: Some evidence concerning the misleading conclusions of Petrinovich and Hardyck. Psychological Bulletin, 1973, 80, 31-32.

Overall, J. E. (Dept. of Neurol. \& Psychiat., Univ. of Texas Med. Branch, Galveston, Tex. 77550), \& Spiegel, D.. K. Comment on "Regression analysis of proportional cell data.' Psychological Bulletin, 1973, $80,28-30$.

\section{Computer Technology}

Hornbeck, F. W. (California State Univ., San Diego, Calif. 92115). Factorial analysis of variance with appended control groups. Behavioral Science, 1973, $18,213-220$.

Lewis, J. L. (Univ. of Washington, Seattle, Wash. 98192), Osgood, G. W., \& Hebert, J. J. Pleiades: Real-time-sharing control in the behavioral science laboratory. Behavior Research Methods \& Instrumentation, 1973, 5, 365-370.

Mulholland, T. B. (Psychophysiol. Lab., VA Hosp., 200 Springs Rd., Bedford, Mass. 01730), \& Goodman, D. ALFIE: Collection of EEG alpha under feedback control using time series analysis. Psychophysiology, $1973,10,437-440$.

Sackett, G. P. (Reg. Primate Rsch. Ctr., Univ. of Washington, Seattle, Wash. 98195), Stephenson, E., \& Ruppenthal, G. C. Digital data acquisition systems for observing behavior in laboratory and field settings. Behavior Research Methods \& Instrumentation, 1973, $5,344-348$.

\section{HUMAN DEVELOPMENT}

Brown, A. L. (Children's Rsch. Ctr., 51 Gerty St., Champaign, Ill. 61820). Judgments of recency for long sequences of pictures: The absence of a developmental trend. Journal of Experimental Child Psychology, 1973, 15, 473-480.

Campione, J. C. (Children's Rsch. Ctr., Univ. of nlinois, Champaign, Il. 61820). The generality of transfer: Effects of age and similarity of training and transfer tasks. Journal of Experimental Child Psychology, $1973,15,407-418$

Faw, T. T. (Univ. of California, Los Angeles, Calif. 90024), \& Nunnally, J. C. The influence of stimulus affective value on children's patterns of visual selection. Journal of Experimental Child Psychology, $1973,15,488-499$.

Fisher, M. A., Sperber, R., \& Zeaman, D. (Univ. of Connecticut, Storrs, Conn. 06268). Theory y and data on developmental changes in novelty preference. Journal of Experimental Child Psychology, 1973, 15, 509-520.

Haney, J. H. (Alderson-Broaddus Coll. \& Sch. of Family Resources and Consumer Services, The Univ. of Wisconsin, Madison, Wis. 53706), \& Hooper, F. H. The Journal of Genetic Psychology, 1973, 122. 235-245.

Harris, P. L. (Dept. of Exptl. Psychol., Univ. of Oxford, 
Oxford, England). Eye movements between adjacent stimuli: An age change in infancy. British Journal of Psychology, 1973, 64, 215-218.

Hass, W. A. (Shimer, Coll., Mt. Carroll, Ill. 61053), \& Wepman, J. M. Constructional variety in the spoken language of school children. The Journal of Genetic Psychology, 1973, 122, 297-308.

Lange, G. (Vassar Coll., Poughkeepsie, N.Y. 12601). The development of conceptual and rote recall skills among school age children. Journal of Experimental Child Psychology, 1973, 15, 394-406.

Offenbach, S. I. (Purdue Univ., Lafayette, Ind. 47901), Baecher, R., \& White, M. Effect of method, instructions, and age on stimulus "preference" assessments. The Journal of Genetic Psychology, $1973,122,253-261$

Rawson, L. M., Tamayo, F. M. V., Vehle, M. T., \& Willemsen, E. W. (Univ. of Santa Clara, Santa Clara, Calif. 95050). Disjunctive concept utilization in preschool children. The Journal of Genetic Psychology, 1973, 122, 211-216.

Rohwer, W. D., Jr. (Inst. of Human Lrng., Univ. of California, Berkeley, Calif. 94720), \& Bean, J. P. Sentence effects and noun-pair learning: A developmental interaction during adolescence. Journal of Experimental Child Psychology, 1973, 15, 521-533

Silleroy, R. S., \& Johnson, P. J. (Univ. of New Mexico, Albuquerque, N.Mex. 87106). The effects of perceptual pretraining on concept identification and preference. Journal of Experimental Child Psychology, 1973, 15, 462-472.

von Wright, J. M. (Univ. of Turku, 20100 Turku, Finland). Relation between verbal recall and visua recognition of the same stimuli in young children. Journal of Experimental Child Psychology, 1973, 15, $481-487$

Welsandt, R. F., Jr., Zupnick, J. J., \& Meyer, P. A (Univ. of South Dakota, Vermillion, S. Dak. 57069). Age effects in backward visual masking (Crawford paradigm). Journal of Experimental Child Psychology, $1973,15,454-461$

\section{PERCEPTUAL AND SENSORY PROCESSES} General

Asso, D. (Univ. of London Goldsmiths' Coll., London, England), \& Wyke, M. Verbal descriptions of spatial relations in line drawings by young children. British Journal of Psychology, 1973, 64, 233-240.

Clement, D. E. (Univ. of South Florida, Tampa, Fla. 33620), \& Schiereck, J. J., Jr. Sex composition and group performance in a visual signal detection task. Memory \& Cognition, 1973, 1, 251-255.

Frey, A. H. (Randomline, Inc., Old York \& Moreland Roads, Willow Grove, Pa. 19090), \& Messenger, R., Jr. Human perception of illumination with pulsed ultrahigh-frequency electromagnetic energy. Science, $1973,181,356-358$.

Ohman, D. W., \& Vitz, P. C. (New York Univ., New York, N.Y. 10003). Complexity ratings of digit strings and their pictorial analogs. Bulletin of the Psychonomic Society, 1973, 2, 45-48.

Shigehisa, T. (Univ. of aberdeen, Aberdeen, Scotland), \& Symons, J. R. Effect of intensity of visual stimulation on auditory sensitivity in relation to personality. British Journal of Psychology, 1973, 64, 205-213.

\section{Vision}

Craske, B. (Univ. of Southampton, Southampton England), \& Crawshaw, M. Latency of autokinesis and convergence of the eyes. British Journal of
Psychology, 1973, 64, 199-204

Cross, H. A. (Colorado State Univ., Fort Collins, Colo. 80521 ). Judgment of rod verticality as a function of subject classification and frame pattern. Bulletin of the Psychonomic Society, 1973, 2, 23-24.

Faw, T. T. (Univ. of California, Los Angeles, Calif. $90024)$. The influence of stimulus affective value on children's patterns of visual selection. Journal of Experimental Child Psychology, 1973, 15, 488-499.

Harris, P. L. (Dept. of Exptl. Psychol., Univ. of Oxford, Oxford, England). Eye movements between adjacent stimuli: An age change in infancy. British Journal of Psychology, 1973, 64, 215-218.

Kao, K. C., \& Dember, W. N. (Univ. of Cincinnati, Cincinnati, Ohio 45221). Effects of size of ring on backward masking of a disk by a ring. Bulletin of the Psychonomic Society, 1973, 2, 15-17.

Newman, C. V. (Univ. of Birmingham, Box 363 , Birmingham B15 2TT, England). Variations in size judgements as a function of surface texture. Quarterly Journal of Experimental Psychology, 1973, 25, 260-264.

Paskewitz, D. A. (Unit for Exptl. Psychiat., Inst. of the Pennsylvania Hosp., 111 N. 49th St., Philadelphia, Pa. 19139 ), Orne, M. T. Visual effects on alpha feedback training. Science, 1973, 181, 360-363.

Redding, G. M. (Illinois State Univ., Normal, Ill. 61761). Simultaneous visual adaptation to tilt and displacement: A test of independent processes. Bulletin of the Psychonomic Society, 1973, 2, 41-42.

Tyler, C. W. (Northeastern Univ., Boston, Mass. 02115) Temporal characteristics in apparent movement: Omega movement vs phi movement. Quarterly Journal of Experimental Psychology, 1973, 25, $182 \cdot 192$.

Welsandt, R. F., Jr., Zupnick, J. J., \& Meyer, P. A. (Univ. of South Dakota, Vermillion, S. Dak. 57069) Age effects in backward visual masking (Crawford paradigm). Journal of Experimental Child Psychology, $1973,15,454-461$.

\section{Audition}

Bever, T. G. (Columbia Univ., New York, N.Y. 10027) Garrett, M. F., \& Hurtig, R. The interaction of perceptual processes and ambiguous sentences. Memory \& Cognition, 1973, 1, 277-286.

Bray, D. A. [Dept. of Head \& Neck Surg. (Audiol.), UCLA Sch. of Med., Los Angeles, Calif. 90024], Dirks, D. D., \& Morgan, D. E. Perstimulatory loudness adaptation. The Journal of the Acoustical Society of America, 1973, 53, 1544-1548.

Domnitz, R. (Ctr. for Communications Sci., Rsch. Lab. of Electronics, M.I.T., Cambridge, Mass. 02139). The interaural time jnd as a simultaneous function of interaural time and interaural amplitude. The Journal of the Acoustical Society of America, 1973, 53, 1549-1552.

Hafter, E. R. (Univ. of California, Berkeley, Calif. 94720), Carrier, S. C., \& Stephan, F. K. Direct comparison of lateralization and the MLD for monaural signals in gated noise. The Journal of the Acoustical Society of America, 1973, 53, 1553-1559.

Morgan, D. E. [Div. of Head \& Neck Surg. (Audiol.), UCLA Sch. of Med., Los Angeles, Calif. 90024 ], \& Dirks, D. D. Suprathreshold loudness adaptation. The Journal of the Acoustical Society of America, 1973, $53,1560-1564$.

Nachshon, I. (Aranne Lab. of Human Psychophysiol., Dept. of Neurol., Hadassah Univ. Hosp., Jerusalem, Israel), \& Carmon, A. Effect of stimulus-response delay on ear superiority for dichotically presented 
digits. Journal of Experimental Psychology, 1973, 99, 288-290.

Patterson, R. D. (Defence \& Civil Inst. of Environmental Med., 1133 Sheppard Ave. W., Downsview, Ont., Canada). The effects of relative phase and the number of components on residue pitch. The Journal of the Acoustical Society of America, 1973, 53, 1565-1572.

Salter, D. (Univ. of Newcastle upon Tyne, Newcastle upon Tyne, England). Capacity and delayed speech. British Journal of Psychology, 1973, 64, 193-198.

Stratton, P. M. (Univ. of Leeds, Leeds, England), \& Connolly, K. Discrimination by newborns of the intensity, frequency and temporal characteristics of auditory stimuli. British Journal of Psychology, 1973, 64, 219-232.

Thurlow, W. R. (Univ. of Wisconsin, Madison, Wis. 53706), \& Jack C. E. Some determinants of localization-adaptation effects for successive auditory stimuli. The Journal of the Acoustical Society of America, 1973, 53, 1573-1577.

Watson, C. S., (Central Inst. for the Deaf, St. Louis, Mo. 63110), Kellogg, S. C., Kawanishi, D. T., \& Lucas, P. A. The uncertain response in detection-oriented psychophysics. Journal of Experimental Psychology, 1973, 99, 180-185.

\section{Other Sense}

Engen, T. (Brown Univ., Providence, R.I. 02912), Kuisma, J. E., \& Eimas, P. D. Short-term memory of odors. Journal of Experimental Psychology, 1973, 99, $222-225$

Kirman, J. H. (Queens Coll. of the CUNY, Flushing, N.Y. 11367). Tactile communication of speech: A review and an analysis. Psychological Bulletin, 1973 , $80,54-74$.

\section{PERFORMANCE}

Caelli, T. M. (Univ. of Newcastle, Newcastle, New South Wales, 23081, Australia), \& Keats, J. A. An extended use of moments of two distribution functions for predicting performance in a pattern discrimination task. Journal of Experimental Psychology, 1973, 99, 209-214.

Lachman, R. (Univ. of Kansas, Lawrence, Kans. 66044). Uncertainty effects on time to access the internal lexicon. Journal of Experimental Psychology, 1973, 99, 199-208

Waag, W. L. (Nav. Aerospace Med. Rsch. Lab., Pensacola, Fla. 32800), Tyler, D. M., \& Halcomb, C. G. Experimenter effects in monitoring performance. Bulletin of the Psychonomic Society, 1973, 1 , 387-388.

Wade, M. G. (Motor Perf. \& Play Rsch. Lab., Univ. of Illinois, Children's Rsch. Ctr., Champaign, Ill. 61820), Ellis, M. J.. \& Bohrer, R. E. Biorhythms in the activity of children during free play. Journal of the Experimental Analysis of Behavior, 1973, 20, 155-162.

\section{Psychomotor Tasks}

Annett, J. (Open Univ., Walton, Bletchley, Bucks, England), \& Sheridan, M. R. Effects of S-R and R-R compatibility on bimanual movement time. Quarterly Journal of Experimental Psychology, 1973, 25, 247-252.

Broadhurst, A. (Univ. of Birmingham, Birmingham, England), \& Eysenck, H. J. Pursuit rotor reminiscence in schizophrenics and normals. Journal of Motor Behavior, 1973, 5, 73-80.

Buckalew, L. W. (South Carolina State Coll., Orangeburg, S.C. 29115). Relationship between a physiological and personality index of excitability. Physiological Psychology, 1973, 1, 158-160.

Clarke, A. M. (Sch. of Behav. Sci., Macquarie Univ., North Ryde, N.S.W., Australia, 2113). Relationship between electromyogram and force of human stretch reflex response for different levels of spindle biasing. Physiology \& Behavior, 1973, 10, 697-700.

Frith, C. D. (Inst. of Psychiat,. Univ. of London, DeCrespigny Park, Denmark Hill, London S.E.5, England). Learning rhythmic hand movements. Quarterly Journal of Experimental Psychology, 1973, $25,253-259$.

Glencross, D. J. (The Flinders Univ. of South Australia, Bedford Park, South Australia 5042). Response complexity and the latency of different movement patterns. Journal of Motor Behavior, 1973, 5, 95-104. Healey, T. R., (Dept. of Physical Ed., East Rochester High Sch., East Rochester, N.Y. 14445), \& Landers, D. M. Effect of need achievement and task difficulty on competitive and noncompetitive motor performance. Journal of Motor Behavior, 1973, 5, 121-128.

Hicks, R. E. (The Univ. of Texas at Austin, Austin, Tex. 78712), \& Powell, G. D. Anticipatory rehearsal in inverted-reversed printing. Journal of Motor Behavior, 1973, 5, 105-109.

Kroll, W. (Dept. of Exercise Sci., Univ. of Massachusetts, Amherst, Mass. 01002). Effects of local muscular fatigue due to isotonic and isometric exercise upon fractionated reaction time components. Journal of Motor Behavior, 1973, 5, 81-93.

Newell, K. M. (Children's Rsch. Ctr., Univ. of Illinois, Urbana-Champaign, Ill. 61820). Journal of Motor Behavior, 1973, 5, 65-72.

Parker, N. K. (Dept. of Physical Ed., Univ. of Illinois, Urbana-Champaign, Ill. 61820). Influence of induced muscular tension on a time-estimation motor task. Journal of Motor Behavior, 1973, 5, 111-120.

\section{Reaction Time}

Angel, A. (Dept. of Physiol., Univ. of Sheffield, Sheffield S10 2TN, England). Input-output relations in simple reaction time experiments. Quarterly Journal of Experimental Psychology, 1973, 25, 193-200.

Baddeley, A. D. (Univ. of Stirling, Stirling, Scotland), \& Ecob, J. R. Reaction time and short-term memory: Implications of repetition effects for the high-speed exhaustive scan hypothesis. Quarterly Journal of Experimental Psychology, 1973, 25, 229-240.

Bernstein, I. H. (Univ. of Texas at Arlington, Arlington, Tex. 76010), Chu, P. K., \& Briggs, P. Stimulus intensity and foreperiod effects in intersensory facilitation. Quarterly Journal of Experimental Psychology, 1973, 25, 171-181.

Biederman, I. (SUNY, Buffalo, N.Y. 14226). Mental set and mental arithmetic. Memory \& Cognition, 1973, 1, 383-386.

Curtis, D. W. (California State Univ., Fullerton, Calif. 92634 ), Paulos, M. A., \& Rule, S. J. Relation between disjunctive reaction time and stimulus difference. Journal of Experimental Psychology, 1973, 2 167-173.

Geller, E. S. (Virginia Polytech. Inst. \& State Univ., Blacksburg, Va. 24061), \& Whitman C. P. Confidence in stimulus predictions and choice reaction time. Memory \& Congnition, 1973, 1, 361-368.

Johnsen, A. M., \& Briggs, G. E. (Human Perf. Ctr., 404-B West 17th Ave., Columbus, Ohio 43210). On the locus of display load effects in choice reactions. Journal of Experimental Psychology, 1973, 99, 266-271 
Sanders, A. F. (Inst. for Percep. TNO, Kampweg 5. Postbus 23, Soesterberg, The Netherlands), \& Wertheim, A. H. The relation between physical stimulus properties and the effect of foreperiod duration on reaction time. Quarterly Journal of Experimental Psychology, 1973, 25, 201-206.

\section{Attention}

Corby, J. C. (c/o Dr. Bert S. Kopell, Dept. of Psychiat., Stanford Univ. Sch. of Med., Stanford, Calif. 94305), $\&$ Kopell, B. S. The effect of predictability on evoked response enhancement in intramodal selective attention. Psychophysiology, 1973, 10, 335-346.

Guralnick, M. J. (National Children's Ctr., Inc., 6200 Second St., NW, Washington. D.C. 20011). Effects of event rate and signal difficulty on observing responses and detection measures in vigilance. Journal of Experimental Psychology, 1973, 99, 261-265.

Hunt, D. (Univ. of Alberta, Edmonton, Alta., Canada) \& Fitzgerald, D. Selective attentional responses and overtraining in a discrimination shift paradigm. Journal of Experimental Child Psychology, 1973, 15, 534-548.

LaBerge, D. (Univ. of Minnesota, Minneapolis, Minn. 55455 ). Attention and the measurement of perceptual learning. Memory \& Cognition, 1973, 1, 268-276.

Schechter, G., \& Buchsbaum, M. (NIMH, Bldg. 10, Rm. 2N.315, Bethesda, Md. 20014). The effects of attention, stimulus intensity, and individual differences on the average evoked response. Psychophysiology, 1973, 10, 392.400.

Townsend, J. T. (Purdue Univ., Layfayette, Ind. 47907), \& Roos, R. N. Search reaction time for single targets in multiletter stimuli with brief visual displays. Memory \& Cognition, 1973, 1, 319-332.

Walley, R. E. (Univ. of Alberta, Edmonton, Alta., Canada), \& Weiden, T. D. Lateral inhibition and cognitive masking: A neuropsychological theory of attention. Psychological Review, 1973, 80, 284-302.

\section{Information Processing}

Erdelyi, M. H. (Douglass Coll., Rutgers Univ., New Brunswick, N.Y. 08903), \& Blumenthal, D. G. Cognitive masking in rapid sequential processing: The effect of an emotional picture on preceding and succeeding pictures. Memory \& Cognition, 1973, 1, 201-204

Ford, J. M. (Dept. of Psychiat., Stanford Univ. Sch. of Med., Stanford, Calif. 94305), Roth, W. T., Dirks, S. J., \& Kopell, B. S. Evoked potential correlates of signal recognition between and within modalities. Science, $1973,181,465-466$.

Levine, D. M. (Bernard Baruch Coll. (CUNY), New York, N.Y. 10010), Wachspress, S., McGuire, P., \& Mayzner, M. S. Visual information processing of numerical inputs. Bulletin of the Psychonomic Society, 1973, 1, 404-406.

\section{Preference}

Bradbury, H. (Univ. of Alberta, Edmonton, Alta., Canada), \& Nelson, T. M. The transitivity of children's inferences about preferences. Bulletin of the Psychonomic Society, 1973, 2, 49-51.

Fisher, M. A., Sperber, R. \& Zeaman, D. (Univ. of Connecticut, Storrs, Conn. 06268). Theory and data on developmental changes in novelty preference. Journal of Experimental Child Psychology, 1973, 15, 509-520.

Offenbach, S. I. (Purdue Univ., Lafayette, Ind. 47901), Baecher, R., \& White, M. Effect of method, instructions, and age on stimulus "preference" assessments. Journal of Genetic Psychology, 1973, $122,253-261$

Silleroy, R. S., \& Johnson, P. J. (Univ. of New Mexico, Albuquerque, N. Mex. 87106). The effects of perceptual pretraining on concept identification and preference. Journal of Experimental Child Psychology, 1973, 15, 462-472.

\section{Sleep and Fatigue}

Hoddes, E. (Dept. of Psychiat., Stanford Univ. Sch. of Med., Stanford, Calif. 94305), Zarcone, V., Smythe, H. Phillips, R., \& Dement, W. C. Quantification of sleepiness: A new approach. Psychophysiology, 1973, $10,431-436$

Naitoh, P. (Navy Med. Neuropsychiat. Rsch. Unit, San Diego, Calif. 92152), Muzet, L. C., Johnson, L. C., \& Moses, J. Body movements during sleep after sleep loss. Psychophysiology, 1973, 10, 363-368.

Townsend, R. E. (Neuropsychiat. Rsch., U.S. Nav. Hosp., Bldg. 36-4E, San Diego, Calif. 92134), Johnson, L. C., \& Muzet. A. Effects of long term exposure to tone pulse noise on human sleep. Psychophysiology, $1973,10,369-376$.

\section{HUMAN LEARNING}

Baum, W. M. (Harvard Univ., Cambridge, Mass. 02138). The correlation-based law of effect. Journal of the Experimental Analysis of Behavior, 1973, 20, $137-158$

\section{Conditioning}

Furedy, J. J. (Univ. of Toronto, Toronto, Ont., M5S 1A1, Canada). Auditory and autonomic tests of the preparatory-adaptive-response interpretation of classical aversive conditioning. Journal of Experimental Psychology, 1973, 99, 280-283.

Furedy, J. J. (Univ. of Toronto, Toronto 181, Ont., Canada), \& Ginsberg, S. Effects of varying signaling and intensity of shock on an unconfounded and novel electrodermal autonomic index in a variable and long-interval classical trace conditioning paradigm. Psychophysiology, 1973, 10, 328-334.

Grings, W. W. (Univ. of Southern Calif., University Park, Los Angeles, Calif. 90007), Schell, A. M., \& Carey, C. A. Verbal control of an autonomic response in a cue reversal situation. Journal of Experimental Psychology, 1973, 99, 215-221.

Lelord, G. (Neurophysiol. \& Exptl. Psychopathol. Lab., Faculté de Médecine, Tours, France), Laffont, F., Jusseaume, P., \& Stephant, J. L. Comparative study of conditioning of averaged evoked responses by coupling sound and light in normal and autistic children. Psychophysiology, 1973, 10, 415-425.

Mandel, I. J. (Dept. of Psychiat., Albert Einstein Coll. of Med., Yeshiva Univ., Bronx, N.Y. 10461), \& Bridger, W. H. Cross-modality transfer of differential galvanic skin response conditioning to word stimuli. Journal of Experimental Psychology, 1973, 99, 157-161.

\section{Discrimination Learning}

Gholson, B. (Hunter Coll. of the CUNY, New York, N.Y. 10021), Phillips, S., \& Levine, M. Effects of the temporal relationship of feedback and stimulus information upon discrimination-learning strategies. Journal of Experimental Child Psychology, 1973, 15, 425-441.

Howell, W. C. (Rice Univ., Houston, Tex. 77001). Effects of organization on discrimination of word frequency within and between categories. Journal of Experimental Psychology, 1973, 99, 255-260.

Spence, J. T. (Univ. of Texas, Austin, Tex. 78712). 
Factors contributing to the effectiveness of social and nonsocial reinforcers in the discrimination learning of children from two socioeconomic groups. Journal of Experimental Child Psychology, 1973, 15, 367-380.

Sperber, R. D. (Univ. of Connecticut, Storrs, Conn. 06268), BGreenfield, D. B., \& House, B. J. A nonmonotonic effect of distribution of trials in retardate learning and memory. Journal of Experimental Psychology, 1973, 99, 186-198.

\section{Verbal Learning}

Lass, N. J. (West Virginia Univ., Morgantown, W. Va. 26505), \& Gasperini, R. M. The verbal transformation effect: A comparative study of the verbal transformations of phonetically trained and non-phonetically trained subjects. British Journal of Psychology, 1973, 64, 183-192.

Rohwer, W. D., Jr. (Inst. of Human Learning, Univ. of California, Berkeley, Calif. 94720), \& Bean, J. P. Sentence effects and noun-pair learning: A developmental interaction during adolescence. Journal of Experimental Child Psychology, 1973, 15, 521-533.

Rowe, E. J. (Memorial Univ. of Newfoundland, St. John's, Newfoundland, Canada), \& Smith, S. K. Imagery effects in continuous paired-associate learning. Journal of Experimental Psychology, 1973, 99, 290-292.

Schipper, L. M. (Bowling Green State Univ., Bowling Green, Ohio 43403), Hanson, B. L., Taylor, G., \& Thorpe, J. A. Semantic and associative factors in probability learning with words. Memory \& Cognition, 1973, 1, 291-296.

Singer, M. (Carnegie-Mellon Univ., Pittsburgh, Pa. 15213). A replication of Bransford and Franks' (1971) "The abstraction of linguistic ideas." Bulletin of the Psychonomic Society, 1973, 1, 416-418.

Wilson, B. J. (Univ. of Missouri, Columbia, Mo. 65201). Reading order and A-B vs B-A performance, Bulletin of the Psychonomic Society, 1973, 2, 39-40.

Yuille, J. C. (Univ. of British Columbia, Vancouver, British Columbia, Canada). A detailed examination of mediation in PA learning. Memory \& Cognition, 1973, $1,333-342$.

\section{Reinforcement}

Croll, W. L. (Carleton Univ., Ottawa 1, Canada). The rational zero point and reinforcement. Bulletin of the Psychonomic Society, 1973, 1, 431-432.

Schaeffer, R. W. (Auburn Univ., Auburn, Ala. 36830), Bauermeister, J. J., \& David, J. H. A test of Premack's "indifference principle." Bulletin of the Psychonomic Society, 1973, 1, 399-401.

\section{HUMAN MEMORY}

Biederman, I. (SUNY, Buffalo, N.Y. 14226). Mental set and mental arithmetic. Memory \& Cognition, 1973, 1, 383-386.

Howell, W. C. (Rice Univ., Houston, Tex. 77001). Representation of frequency in memory. Psychological Bulletin, 1973, 80, 44-53.

Lange, G. (Vassar Coll., Poughkeepsie, N.Y. 12601). The development of conceptual and rate recall skills among school age children. Journal of Experimental Child Psychology, 1973, 15, 394-406.

Light, L. L. (Pitzer Coll., Claremont, Calif. 91711), Stansbury, C., Rubin, C., \& Linde, S. Memory for modality of presentation: Within-modality discrimination. Memory \& Cognition, 1973, 1 . $395 \cdot 400$.
Schmitt, J. C. (State Univ. Coll., Oswego, N.Y. 13126), \& Forrester, W. E. Effects of stimulus concreteness-imagery and arousal on immediate and delayed recall. Bulletin of the Psychonomic Society, $1973,2,25 \cdot 26$.

Shebilske, W., \& Epstein, W. Effect of forget instructions with and without the conditions for selective search. Memory \& Cognition, 1973, 1, 261-267.

\section{Long-Term Memory}

Allison, K. C. (135 Elmdale Ave., Akron, Ohio 44313), Newman, S. E., \& Ford, W. S. Memory for noun pairs in the same or different underlying strings. Memory \& Cognition, 1973, 1, 205-208.

Blake, M. (Univ. of Toronto, Toronto 181, Canada). Prediction of recognition when recall fails: Exploring the feeling-of-knowing phenomenon. Journal of Verbal Learning \& Verbal Behavior, 1973, 12, 311-319.

Brown, A. L. (51 Gerty St., Champaign, Ill. 61820). Judgments of recency for long sequences of pictures: The absence of a developmental trend. Journal of Experimental Child Psychology, 1973, 15, 473-480.

Carey, S. T. (Univ. of Alberta, Edmonton, Alta., Canada), \& Lockhart, R. S. Encoding differences in recognition and recall. Memory \& Cognition, 1973, 1, 297-300.

Clifton, C., Jr. (Univ. of Massachusetts, Amherst, Mass. 01002), Cruse, D., \& Gutschera, K. D. Recoding processes in recognition: Some effects of presentation rate. Memory \& Cognition, 1973, 1, 387-394.

Clifton, C., Jr. (Univ. of Massachusetts, Amherst, Mass. 01002), \& Tash, J. Effect of syllabic word length on memory-search rate. Journal of Experimental Psychology, 1973, 99, 231-235.

De Vito, C. (Brooklyn Coll., New York, N.Y. 11210), \& Olson, A. M. More on imagery and the recall of adjectives and nouns from meaningful prose. Bulletin of the Psychonomic Society, 1973, 1, 397-398.

Elias, C. S., \& Perfetti, C. A. (Lrng. Rsrch. \& Devel. Ctr., Univ. of Pittsburgh, Pittsburgh, Pa. 15260). Encoding task and recognition memory: The importance of semantic encoding. Journal of Experimental Psychology, 1973, 99, 151-156.

Foth, D. L. (Univ. of British Columbia, Vancouver 8, B.C., Canada). Mnemonic technique effectiveness as a function of word abstractness and mediation instructions. Journal of Verbal Learning \& Verbal Behavior, 1973, 12, 239-245.

Gardiner, J. M. (Dept. of Soc. Sci. \& Humanities, City Univ., London, E.C.1, England), Craik, F. I. M., \& Bleasdale, F. A. Retrieval difficulty and subsequent recall. Memory \& Cognition, 1973, 1, 213-216.

Herrmann, D. J. (Stanford Univ., Stanford, Calif. 94305), \& McLaughlin, J. P. Effects of experimental and preexperimental organization on recognition: Evidence for two storage systems in long-term memory. Journal of Experimental Psychology, 1973, 99, 174-179.

Hintzman, D. L. (Univ. of Oregon, Eugene, Oreg. 97403), Block, R. A., \& Summers, J. J. Modality tags and memory for repetitions: Locus of the spacing effect. Journal of Verbal Learning \& Verbal Behavior, $1973,12,229-238$.

Homa, D. (Div. of Natural Sci., New Coll., Sarasota, Fla. 33578). Organization and long-term memory search. Memory \& Cognition, 1973, 1, 369-379.

Jacoby, L. L. (Iowa State Univ., Ames, Iowa 50010). Encoding processes, rehearsal, and recall requirements. Journal of Verbal Learning \& Verbal Behavior, 1973, 12, 302-310. 
Kennedy, A. (Univ. of Dundee, Dundee, Scotland). Associative encoding of words in passive sentences. British Journal of Psychology, 1973, 64. 169-172.

Kolers, P. A. (Univ. of Toronto, Toronto. Ont., Canada M5S 1A1). Remembering operatins. Memory \& Cognition, 1973, 1, 347-355.

Madigan, S. (Univ. of Southern California, Los Angeles, Calif. 90007). Effects of overt rehearsal on recall of paired associates. Bulletin of the Psychonomic Society, 1973, 1, 423-424.

Morris, P. E. (Univ. of Exeter, Exeter, England), \& Reid, R. L. Recognition and recall: Latency and recurrence of images. British Journal of Psychology, 1973, 64, 161-167.

Reed, A. V. (Univ. of Oregon, Eugene, Oreg. 97403). Speed-accuracy trade-off in recognition memory. Science, 1973, 181, 574-576.

Schulman, A. I. (Univ. of Virginia, Charlottesville, Va. $22901)$. Recognition memory and the recall of spatial location. Memory \& Cognition, 1973, 1, 256-260.

Sperber, R. D. (Univ. of Connecticut, Storrs, Conn. 06268), Greenfield, D. B., \& House, B. J. A nonmonotonic effect of distribution of trials in retardate learning and memory. Journal of Experimental Psychology, 1973, 99, 186-198.

Standing, L. (Univ. of St. Andrews, Fife, Scotland). Learning 10,000 pictures. Quarterly Journal of Experimental Psychology, 1973, 25, 207-222.

Tolin, P. (Central Washington State Coll., Ellensburg, Wash. 98926), \& Delegans, G. M. The effect of stimulus complexity on retrieval of information from memory. Memory \& Cognition, $1973,1,380-382$.

Underwood, B. J. (Northwestern Univ., Evanston, Ill. 60201), \& Zimmerman, J. Serial retention as a function of hierarchical structure. Joutnal of Experimental Psychology, 1973, 99, 236-242.

von Wright, J. M. (Univ. of Turku, 20100 Turku, Finland). Relation between verbal recall and visual recognition of the same stimuli in young children. Journal of Experimental Child Psychology, 1973, 15, 481-487.

Watkins, M. J. (Yale Univ., New Haven, Conn. 06510), \& Watkins, O. C. The postcategorical status of the modality effect in serial recall. Journal of Experimental Psychology, 1973, 99, 226-230.

Wood, G. (Michigan State Univ., East Lansing, Mich. 48823), \& Pennington, J. Encoding and retrieval from long-term storage. Journal of Experimental Psychology, 1973, 99, 243-254.

Yarmey, A. D. (Univ. of Guelph, Guelph, Ont., Canada). I recognize your face but I can't remember your name: Further evidence on the tip-of-the-tongue phenomenon. Memory \& Cognition, 1973, 1, 287-290.

\section{Free Recall}

Brenner, M. (Univ. of Michigan, Ann Arbor, Mich. 48104 ). The next-in-line effect. Journal of Verbal Learning \& Verbal Behavior, 1973, 12, 320-323.

Jacoby, L. L. (Iowa State Univ., Ames, Iowa 50010), \& Goolkasian, P. Semantic versus acoustic coding: Retention and conditions of organization. Journal of Verbal Learning \& Verbal Behavior, 1973, 12, 324-333.

Petrich, J. A. (Univ. of Pittsburgh, Pittsburgh, Pa. 15213). Organization of recall in the retroactive inhibition paradigm. Journal of Verbal Learning \& Verbal Behavior, 1973, 12, 294-301.

\section{Short-Term Memory}

Baddeley, A. D. (Univ. of Stirling, Stirling, Scotland), \&
Ecob, J. R. Reaction time and short-term memory Implications of repetition effects for the high-speed exhaustive scan hypothesis. Quarterly Journal of Experimental Psychology, 1973, 25, 229-240.

Engen, T. (Brown Univ., Providence, R.I. 02912), Kuisma, J. E., \& Eimas, P. D. Short-term memory of odors. Journal of Experimental Psychology, 1973, 99, $222 \cdot 225$

Forrin, B. (Div. of Sci., Scarborough Coll., Univ. of Toronto, West Hill, Ont., Canada), \& Cunningham, K. Recognition time and serial position of probed item in short-term memory. Journal of Experimental Psychology, 1973, 99, 272-279.

Morin, R. E. (State Univ. of Northern Iowa, Cedar Falls, Iowa 50613), Konick, D. S., \& Hoving, K. L. Reduction of redundant stimulus information in short-term memory. Bulletin of the Psychonomic Society, 1973, 2, 29-30.

Parkinson, S. R. (Arizona State Univ., Tempe, Ariz. 85281), Kroll, N. E. A., \& Parks, T. E. Short-term retention of superimposed and of spatially distinct multiletter visual arrays. Memory \& Cognition, 1973 , 1. 301-303.

Tzeng, O. J. L. (Ohio State Univ., Columbus, Ohio 43210). Stimulus meaningfulness, encoding variability, and the spacing effect. Journal of Experimental Psychology, 1973, 99, 162-166.

Well, A. D. (Univ. of Massachusetts, Amherst, Mass. 01002), \& Sonnenschein, B. Effects of irrelevant stimulus dimensions on selection in immediate memory. Journal of Experimental Psychology, 1973, 99, 283-285.

Transfer

Campione, J. C. (Children's Rsrch. Ctr., Univ. of Illinois, Champaign, Ill. 61820). The generality of transfer: Effects of age and similarity of training and transfer tasks. Journal of Experimental Child Psychology, $1973,15,407-418$.

Grabe, M. (Iowa State Univ., Ames, Iowa 50010). Interference and encoding processes. Bulletin of the Psychonomic Society, 1973, 2, 13-15.

\section{HUMAN THINKING}

Bradbury, H. (Univ. of Alberta, Edmonton, Alta., Canada), \& Nelson, T. M. The transitivity of children's inferences about preferences. Bulletin of the Psychonomic Society, 1973, 2, 49-51.

Chris, S. A. (Univ. of Windsor, Windsor 11, Ont., Canada), \& Woodyard, H. D. Self-perception and characteristics of premanipulation attitudes: A test of Bem's theory. Memory \& Cognition, 1973, 1, 229-235.

Cromer, R. F. (Med. Rsrch. Council Devel. Psychol. Unit, Gordon St., London, England). Conservation by the congenitally blind. British Journal of Psychology, $1973,64,241-250$.

Horn, J. L. (Univ. of Denver, Denver, Colo. 80210), \& Knapp, J. R. On the subjective character of the empirical base of Guilford's structure-of-intellect model. Psychological Bulletin, 1973, 80, 33-43.

Kahneman, D. (Hebrew Univ., Jerusalem, Israel), \& Tversky, A. On the psychology of prediction. Psychological Review, 1973, 80, 237-251.

Mischel, W. (Stanford Univ., Stanford, Calif. 94305). Toward a cognitive social learning reconceptualization of personality. Psychological Review, 1973, 80, $252-283$

Pylyshyn, Z. W. (Univ. of Western Ontario, London N6A $3 \mathrm{~K} 7$, Ont., Canada). What the mind's eye tells the mind's brain: A critique of mental imagery. 
Psychological Bulletin, 1973, 80, 1-24

Vickers, M.. \& Blanchard, E. B. (Univ. of Georgia, Athens, Ga. 30601). The development of preference for cognitive balance. Journal of Genetic Psychology, $1973,122,189-195$

\section{Verbal Processes}

Asso, D. (Univ. of London Goldsmiths' Coll., London, England), \& Wyke, M. Verbal descriptions of spatial relations in line drawings by young children. British Journal of Psychology, 1973, 64, 233-240.

Baron, J. (McMaster Univ., Hamilton, Ont., Canada). Phonemic stage not necessary for reading. Quarterly Journal of Experimental Psychology, 1973, 25, 241-246.

Bever, T. G. (Columbia Univ., New York, N.Y. 10027), Garrett, M. F., \& Hurtig, R. The interaction of perceptual processes and ambiguous sentences. Memory \& Cognition, 1973, 1, 277-286.

Bjork, E. L. (Univ. of Michigan, Ann Arbor, Mich. 48104), \& Estes, W. K. Letter identification in relation to linguistic context and masking conditions. Memory \& Cognition, 1973, 1, 217-223.

Bobrow, S. A., \& Bell, S. M. (Univ. of Washington, Seattle, Wash. 98195). On catching on to idiomatic expressions. Memory \& Cognition, 1973, 1, 343-346.

Foss, D. J. (Univ. of Texas, Austin, Tex. 78712), \& Swinney, D. A. On the psychological reality of the phoneme: Perception, identification, and consciousness. Journal of Verbal Learning \& Verbal Behavior, 1973, 12, 246-257.

Grieve, R., \& Wales, R. J. (Univ. of Edinburgh, Edinburgh, Scotland). Passives and topicalization. British Journal of Psychology, 1973, 64, 173-182.

Haney, J. H. (Alderson-Broaddus Coll. \& Sch. of Family Resources \& Consumer Services, Univ. of Wisconsin, Madison, Wis. 53706), \& Hooper, F. H. A developmental comparison of social class and verbal ability influences on Piagetian tasks. Journal of Genetic Psychology, 1973, 122, 235-245.

Hass, W. A. (Shimer Coll., Mt. Carroll, Ill. 61053), \& Wepman, J. M. Constructional variety in the spoken language of school children. Journal of Genetic Psychology, 1973, 122, 297-308.

Holmes, V. M. (Univ. of Melbourne, Parkville, Victoria, 3052, Australia). Order of main and subordinate clauses in sentence perception. Journal of Verbal Learning \& Verbal Behavior, 1973, 12, 285-293.

Kennedy, A. (Univ. of Dundee, Dundee, Scotland). Associative encoding of words in passive sentences. British Journal of Psychology, 1973, 64, 169-172.

Singer, M. (Carnegie-Mellon Univ., Pittsburgh, Pa. 15213), \& Rosenberg, S. T. The role of grammatical relations in the abstraction of linguistic ideas. Journal of Verbal Learning \& Verbal Behavior, 1973, 12, $273-284$.

Springston, F. J. (Stanford Univ., Stanford, Calif. 94305), \& Clark, H. H. And and or, or the comprehension of pseudoimperatives. Journal of Verbal Learning \& Verbal Behavior, 1973, 12 , 258-272.

\section{Problem Solving}

Biederman, I. (SUNY, Buffalo, N.Y. 14226). Mental set and mental arithmetic. Memory \& Cognition, 1973,1, 383-386.

Erickson, G. M. (Grad. Sch. of Business, Stanford Univ., Stanford, Calif. 94305). Maslow's basic needs theory and decision theory. Behavioral Science, 1973, 18, $210-211$.

Gormly, J. (Rutgers, The State Univ., New Brunswick,
N.J. 08903). The influences of normative information on human judgmental processes. Bulletin of the Psychonomic Society, 1973, 1, 414-416.

Streufert. S. C. (Purdue Univ., West Lafayette, Ind $47907)$. Effects of information relevance on decision making in complex environments. Memory \& Cognition, 1973, 1, 224-228.

\section{Concepts}

Lange, G. (Vassar Coll., Poughkeepsie, N.Y. 12601). The development of conceptual and rote recall skills among school age children. Journal of Experimental Child Psychology, 1973, 15, 394-406.

McGlynn, R. P. (Texas Tech Univ., Lubbock, Tex. 79409), \& Schick, C. Reduced information feedback on a selection concept learning task. Behavior Research Methods \& Instrumentation, 1973, 5, 355-356.

Nahinsky, I. D. (Univ. of Louisville, Louisville, Ky. 40208), Slaymaker, F. L., Aamiry, A., \& O'Brien, C. $\mathrm{J}$. The concreteness of attributes in concept learning strategies. Memory \& Cognition, 1973, 1, 307-318.

Rawson, L. M., Tamayo, F. M. V., Vehle, M. T., \& Willemsen, E. W. (Univ. of Santa Clara, Santa Clara, Calif. 95050). Disjunctive concept utilization in preschool children. Journal of Genetic Psychology, $1973,122,211-216$.

Richman, C. L. (Wake Forest Univ., Winston-Salem, N.C. 27109). Role of overtraining in reversal and conceptual shift behavior. Journal of Experimental Psychology, 1973, 99, 285-287.

Silleroy, R. S., \& Johnson, P. J. (Univ. of New Mexico, Albuquerque, N. Mex. 87106). The effects of perceptual pretraining on concept identification and preference. Journal of Experimental Child Psychology, 1973, 15, 462-472.

\section{SOCIAL PROCESSES}

Lebin, I. P. (Univ. of Iowa, Iowa City, Iowa 52242). Learning effects in information integration: Manipulation of cue validity in an impression formation task. Memory \& Cognition, 1973, 1, 236-240.

Lugg, A. M., \& Gollob, H. F. (Univ. of Denver, Denver, Colo. 80210). An adding result in impression formation. Memory \& Cognition, 1973, 1, 356-360.

Mischel, W. (Stanford Univ., Stanford, Calif. 94305). Toward a cognitive social learning reconceptualization of personality. Psychological Review, 1973, 80, $252 \cdot 283$

Social Influences

Mills, J. (Univ. of Maryland, College Park, Md. 20742), \& Kimble, C. E. Opinion change as a function of perceived similarity of the communicator and subjectivity of the issue. Bulletin of the Psychonomic Society, 1973, 2, 35-36.

Nacci, P. (SUNY, Albany, N.Y. 12222), \& Tedeschi, J. T. Trust and reactions to threats. Bulletin of the Psychonomic Society, 1973, 1, 421-422.

Spence, J. T. (Univ. of Texas, Austin, Tex. 78712). Factors contributing to the effectiveness of social and nonsocial reinforcers in the discrimination learning of children from two socioeconomic groups. Journal of Experimental Child Psychology, 1973, 15, 367-380.

Wilcox, B., Meddock, T. D., \& Steinman, W. M. (Children's Rsrch. Ctr., Univ. of Illinois, Urbana-Champaign, Ill. 61820). "Generalized imitation" on a nonimitative task: Effects of modeling and task history. Journal of Experimental Child Psychology, 1973, 15, 381-393. 
Social Interaction

Clement. D. E. (Univ. of South Florida, Tampa. Fla. 33620 ), \& Schiereck, J. J., Jr. Sex composition and group performance in a visual signal detection task. Memory \& Cognition, 1973, 1, 251-255.

England, J. L. (Brigham Young Univ., Provo, Utah 84601 ). Mathematical models of two-party negotiations. Behavioral Sciences, 1973, 18, 189-197.

Griesinger, D. W. (Inst. of Admin. \& Mgt., Union Coll., Schenectady, N.Y. 12308), \& Livingston, J. W., Jr. Toward a model of interpersonal motivation in experimental games. Behavioral Science, 1973, 18, 173-188.

Harris, V. A. (SUNY, Buffalo, N.Y. 14226), \& Robinson, C. E. Bystander intervention: Group size and victim status. Bulletin of the Psychonomic Society, 1973, 2, 8-10.
Kniveton, B. H. (Dept. of Adult Ed., Univ, of Nottingham, Nottingham, England). The effect of rehearsal delay on long-term imitation of filmed aggression. British Journal of Psychology, 1973, 64, 259-265.

Paulus, P. (Univ. of Texas, Arlington, Tex. 76010), McCain, G., \& Cox, V. A note on the use of prisons as environments for investigation of crowding. Bulletin of the Psychonomic Society, 1973, 1, 427-428.

Penner, L. A. (Univ. of South Florida, Tampa, Fla. 33620), Hawkins, H. L., Dertke, M. C., Spector, P., \& Stone, A. Obedience as a function of experimenter competence. Memory \& Cognition, 1973, 1, 241-245.

Stephenson, G. M. (Univ. of Nottingham, Nottingham, England), Rutter, D. R., \& Dore, S. R. Visual interaction and distance. British Journal of Psychology, 1972, 64, 251-257.

\section{ANIMAL LEARNING AND BEHAVIOR}

\section{METHODS}

Berger, L. H. (Univ. of Montana, Missoula, Mont. 59801), \& Kettlewell, N. M. A balance panel, amplifier, and trigger device for nictitating membrane transducers. Behavior Research Methods \& Instrumentation, 1973, 5, 341-343.

Bertsch, G. J. (Univ. of New Hampshire, Durham, N.H. 03824), \& Becker, R. An inexpensive food-peck recorder for pigeons. Journal of the Experimental Analysis of Behavior, 1973, 20, 71-72.

Bushnell, P. J. (Reg. Primate Rsrch. Ctr., Univ. of Wisconsin, Madison, Wis. 53706), Henry, K. R., \& Bowman, R. E. The intercalated reinforcement technique: Learning without differential total reinforcement between groups. Behavior Research Methods \& Instrumentation, 1973, 5, 337-339.

Gold, R. M. (SUNY, Cortland, N.Y. 13045), Kapatos, G., \& Carey, R. J. A retracting wire knife for stereotaxic brain surgery made from a microliter syringe. Physiology \& Behavior, 1973, 10, 813-815.

Hall, R. D. (Rsch. Lab. of Electronics, M.I.T., Cambridge, Mass. 02139). Some properties of conditioned and unconditioned eyelid reflexes in the albino rat. Behavior Research Methods \& Instrumentation, $1973,5,321-331$.

Hornbeck, F. W. (California State Univ., San Diego, Calif. 92115). Factorial analysis of variance with appended control groups. Behavioral Science, 1973, 18, 213-220.

Kalinoski, R. (Univ. of New Mexico, Albuquerque, N. Mex. 87104), \& Gluck, J. P. An inexpensive, efficient cage for small birds. Behavior Research Methods \& Instrumentation, 1973, 5, 353-354.

Kaplan, J. (Life Sci. Div., Stanford Rsrch. Inst., Menlo Park, Calif. 94025), \& Russell, M. A surrogate for rearing infant squirrel monkeys. Behavior Research Methods \& Instrumentation, 1973, 5, 379-80.

Lewis, P. (Ohio Univ., Athens, Ohio 45701), Muehleisen, P., \& Stoyak, M. A technique for programming long interval schedules. Journal of the Experimental Analysis of Behavior, 1973, 20, 16.

Medin, D. L. (Rockefeller Univ., New York, N.Y. 10021). Subproblem analysis of discrimination shift learning. Behavior Research Methods \& Instrumentation, 1973, 5, 332-336.

Morrison, J. E. (Wake Forest Univ., Winston-Salem, N.C. 27109), Spevack, A. A., \& Yezierski, R. The effects of response-dependent and response-independent methods on delayed alternation. Behavior Research Methods \& Instrumentation, 1973, 5, 361-363.
Wald, E. D. (Univ. of Denver, Denver, Colo. 80210), Mackinnon, J. R., \& Desiderato, O. Production of gastric ulcers in the unrestrained rat. Physiology \& Behavior, 1973, 10, 825-827.

Wallace, R. F. (Univ. of California, San Diego, La Jolla, Calif. 92037). A multifunction multirange interval timer. Behavior Research Methods \& Instrumentation, 1973, 5, 380-381.

Webster, D. M. (Univ. of Auckland, Private Bag, Auckland, New Zealand), \& Hollard, V. D. A safe and simple injection anesthetic for birds. Physiology \& Behavior, 1973, 10, 831.

\section{DEVELOPMENT}

Schulman, A. H. (Virginia Polytech. Inst. \& State Univ., Blacksburg, Va. 24061). Transitivity of social choice: Developmental considerations. Bulletin of the Psychonomic Society, 1973, 1, 425-426.

\section{Genetics}

Goodrick, C. L. (Gerontol. Rsch. Ctr., Baltimore City Hosps., Baltimore, Md. 21224). Exploration activity and emotionality of albino and pigmented mice: Inheritance and effects of test illumination. Journal of Comparative \& Physiological Psychology, 1973, 84, 73-81.

Jakubczak, L. F. (Gerontol. Psychol. Lab., VA Hosp., St. Louis, Mo. 63125). Age differences in caloric-density preference as a function of strain of rats. Bulletin of the Psychonomic Society, 1973, 1, 395-396.

Sherrod, K. B. (Fisk Univ., Nashville, Tenn. 37203). Effects of irradiation and/or handling on shuttle box performance of C57 Bl/6 mice. Physiology \& Behavior, $1973,10,721.724$.

Van Abeelen, J. (Genetics Lab., Univ. of Nijmegen, Drichuizerweg 200, The Netherlands), Daems, J., \& Douma, G. Memory storage in three inbred mouse strains after injection of cycloheximide. Physiology \& Behavior, 1973, 10, 751-753.

\section{Early Development}

Dunlap, J. L. (Tulane Univ., New Orleans, La. 70118), Gerall, A. A., \& McLean, L. D. Enhancement of female receptivity in neonatally castrated males by prepuberal ovarian transplants. Physiology \& Behavior, 1973, 10, 701-705.

Hahn, M. E. (SUNY, Binghamton, N.Y. 13901), Haber, S. B., \& Fuller, J. L. Differential agonistic behavior in mice selected for brain weight. Physiology \& 
Behavior, 1973, 10,759-762.

Heaton, M. B. (Div. of Rsrch., North Carolina Dept. of Mental Health, Raleigh, N.C. 27611). Early visual function in bobwhite and Japanese quail embryos as reflected by pupillary reflex. Journal of Comparative \& Physiological Psychology, 1973, 84, 134-139.

Kaplan, J. (Life Sci. Div., Stanford Research Inst., Menlo Park, Calif. 94025), \& Russell, M. A surrograte for rearing infant squirrel monkeys. Behavior Research Methods \& Instrumentation, 1973, 5, 379-380.

Nagy, Z. M. (Bowling Green State Univ., Bowling Green, Ohio 43403). Effect of turn preference upon development of discriminated T-maze training ability of infant mice. Bulletin of the Psychonomic Society, $1973,1,441-442$.

Sherrod, K. B. (Fisk Univ., Nashville, Tenn. 37203). Effects of irradiation and/or handling on shuttle box performance of $\mathrm{C} 57 \mathrm{Bl} / 6$ mice. Physiology \& Behavior, $1973,10,721-724$

Strobel, M. G. (Univ. of Montreal, C.P. 6128, Montreal 101, P.Q., Canada), Freedman, S. L., \& Kamra, O. P. Radiosensitive period of pecking response during embryological development of domestic chicks. Journal of Comparative \& Physiological Psychology, $1973,84,82-87$

Wise, L. A. (Univ. of Montana, Missoula, Mont. 59801), Zimmermann, R. R., \& Strobel, D. A. Dominance measurements of low and high protein reared rhesus macaques. Behavioral Biology, 1973, 8, 77-84.

Wright, J. W. (Fordham Univ., Bronx, N.Y. 10458). Adaptation to long-term forced saline consumption during postweaning in rats. Physiological Psychology, $1973,1,185-187$

\section{MOTIVATION AND EMOTION}

Cattell, R. B. (Univ. of Ilinois, Urbana, Ill. 61801), \& Korth, B. The isolation of temperament dimensions in dogs. Behavioral Biology, 1973, 9, 15-30.

Cohen, J. S. (Univ. of Windsor, Windsor 11, Ont., Canada), \& Sullivan, B. Effects of drive level on cue utilization of spatially separated redundant relevant cues. Bulletin of the Psychonomic Society, 1973, 1, 455-457.

Keyes, J. B. (Louisiana State Univ., Baton Rouge, La. 70803 ), \& Dempsey, G. L. The effect of motivational states on ECS-induced perseveration. Physiological Psychology, 1973, 1, 133-135.

Ley, K. F. (Univ. of Vermont, Burlington, Vt. 05401), \& Corson, J. A. Effects of ACTH, adrenalectomy and time of day on emotional activity of the rat. Behavioral Biology, 1973, 9, 111-115.

Tarte, R. D. (Univ. of Nevada, Las Vegas, Nev. 89154), \& Snyder, R. L. Some sources of variation in the bar-pressing versus freeloading phenomenon in rats. Journal of Comparative \& Physiological Psychology, $1973,84,128-133$

\section{Activity and Exploratory Behavior}

Barnett, S. A. (Dept. of Zool., Australian National Univ. Canberra, A.C.T. 2600, Australia), \& McEwan, I. M. Movements of virgin, pregnant and lactating mice in a residential maze. Physiology \& Behavior, 1973, 10, 741-746.

Enns, M. P. (St. Lawrence Univ., Canton, N.Y. 13617), \& Remley, N. R. Effects of activity on the rate of barpressing by rats. Physiological Psychology, 1973, $1,115-117$.

Fried, P. A. (Carleton Univ., Ottawa, Canada). The septum and hyper-reactivity: A review. British Journal of Psychology, 1973, 64, 267-275.

Goodrick, C. L. (Gerontol. Rsch. Ctr.. Baltimore City
Hosps., Baltimore, Md. 21224). Exploration activity and emotionality of albino and mice: Inheritance and effects of tested illumination. Journal of Comparative \& Physiological Psychology, 1973, 84, 73-81.

Modigh, K. (Dept. of Pharmacol., Univ. of Göteborg, Göteborg, Sweden). Effects of L-tryptophan on motor activity in mice. Psychopharmacologia (Berlin), $1973,30,123 \cdot 134$.

Shashona, V. E. (McLean Hosp. Rsrch. Lab., Dept. of Biol. Chem., Harvard Med. Sch., Belmont, Mass. 02178). Seasonal changes in the learning and activity patterns of goldfish. Science, 1973, 181, 572-574.

Smith D. F (Psychopharmacol. Rsrch. Unit. Statshospitalet, 8240 Risskov, Denmark), \& Smith, H. $B$. The effect of prolonged lithium administration on activity, reactivity, and endurance in the rat. Psychopharmacologia (Berlin), 1973, 30, 83-88.

Ward, J. E. (California State Univ., Sacramento, Calif 95819), \& Doolittle, J. H. The effect of the anterior ganglia on forward movements in the earthworm. Physiological Psychology, 1973, 1, 129-132.

\section{Hunger and Thirst}

Blundell, J. E. (Univ. of Leeds, Leeds, LS2 9JT, England), \& Herberg, L. J. Effectiveness of lateral hypothalamic stimulation, arousal, and food deprivation in the initiation of hoarding behaviour in naive rats. Physiology \& Behavior, 1973, 10, 763-767.

Czech, D. A. (Marquette Univ., Milwaukee, Wis. 53233). Effects of amygdalar lesions on eating and drinking and saline preference in the rat. Physiology \& Behavior, 1973, 10, 821-823.

Dubuc, P. U. (Dept. of Metabolism \& Endocrinol., City of Hope National Med. Ctr., Duarte, Calif. 91010), \& Reynolds, R. W. Hypothalamic metallic deposition and the production of experimental obesity. Physiology \& Behavior, 1973, 10, 677-681.

Griffin, P. (Univ. of Alabama, University, Ala. 35486), Medearis, H. D., \& Hughes, W. R. Food deprivation and free-operant avoidance in the pigeon. Bulletin of the Psychonomic Society, 1973, 1, 393-394.

Keesey, R. E. (Univ. of Wisconsin, Madison, Wis. 53706 ), \& Boyle, P. C. Effects of quinine adulteration upon body weight of LH-lesioned and intact male rats. Journal of Comparative \& Physiological Psychology, 1973, 84, 38-46.

Kutscher, C. L. (Syracuse Univ., Syracuse, N.Y. 13210). Food-deprivation polydipsia in gerbils: Lack of adaptive value and termination with carbohydrate feeding. Physiological Psychology, 1973, 1, 125-128.

Panksepp, J. (Bowling Green State Univ., Bowling Green, Ohio 43403). The ventromedial hypothalamus and metabolic adjustments of feeding behavior. Behavioral Biology, 1973, 9, 65-75.

Schaeffer, R. W. (Auburn Univ., Auburn, Ala. 36830), \& David, M. Lick rates in New Zealand white rabbits. Bulletin of the Psychonomic Society, 1973, 2, 43-44.

Sieck, M. H. (Univ. of California, Riverside, Calif. 92502). Selective olfactory system lesions in rats and changes in appetitive and aversive behavior. Physiology \& Behavior, 1973, 10, 731-739.

Singh, D. (Univ. of Texas, Austin, Tex. 78712). Effects of preoperative training on food-motivated behavior of hypothalamic hyperphagic rats. Journal of Comparative \& Physiological Psychology, 1973, 84, 47-52.

Strouthes, A. (SUNY, Binghamton, N.Y. 13901). Saccharin drinking and mortality in rats. Physiology \& Behavior, 1973, 10, 781-791.

Wedeking, P. W. (Dept. of Pharmacol., Squibb Inst. for Med. Rsrch., Princeton, N.J. 08540). Comparison of 
chlordiazepoxide and food deprivation in rats on a fixed-ratio satiation schedule. Physiology \& Behavior, $1973,10,707-710$.

\section{Physiological Factors}

Carmona, A. (Departamento de Fisiologia y Biofisica, Facultad de Medicina, Universidad de Chile, Casilla 6524, Santiago, Chile), \& Slangen, J. Effects of chemical stimulation of the hypothalamus upon gastric secretion. Physiology \& Behavior, 1973, 10, $657-661$

Deaux, E. (Antioch Coll., Yellow Springs, Ohio 45387), \& Engstrom, R. The temperature of ingested water Its effect on body temperature. Physiological Psychology, 1973, 1, 152-154.

Jalowiec, J. E. (Worcester Fndtn. for Exptl. Biol., Shrewsbury. Mass. 01545), Panksepp, J., Shabshelowitz, H., Zolovick, A. J., Stern, W., \& Morgane, P. J. Suppression of feeding in cats following 2-deoxy-D-glucose. Physiology \& Behavior, $1973,10,805-807$.

Le Magnen, J. (Coll. de France, Paris, France), Devos, M. Gaudillière, J.-P., Louis-Sylvestre, J., \& Tallon, S. Role of a lipostatic mechanism in regulation by feeding of energy balance in rats. Journal of Comparative \& Physiological Psychology, 1973, 84, $1 \cdot 23$.

\section{Preferences}

Jakubczak, L. F. (Gerontol. Psychol. Lab., VA Hosp., St. Louis, Mo. 63125). Age differences in caloric-density preference as a function of strain of rats. Bulletin of the Psychonomic Society, 1973, 1, 395-396

Krecek, J. (Inst. of Physiol., Czechoslovak Acad. of Sci., Prague, Czechoslovakia). Sex differences in salt taste: The effect of testosterone. Physiology \& Behavior, $1973,10,683-688$

Levy, C. J. (SUNY, Albany, N.Y. 12222). Preference for sodium chloride over sodium carbonate by sodium deficient rats. Physiology \& Behavior, 1973, 10, $829 \cdot 830$

Rogers, J. G., Jr. (Patuxent Wildlife Rsrch. Ctr., Laurel, Md. 20810), \& Maller, O. Effect of salt on the response of birds to sucrose. Physiological Psychology, 1973, 1, 199-200.

Rosen, E. F. (Coll. of William \& Mary, Williamsburg, Va. 23185), Petty, L. C., \& Angelo, W. L. The role of the medium in sodium saccharin preference in rats. Physiological Psychology, 1973, 1, 149-151.

Wright, J. W. (Fordham Univ., Bronx, N.Y. 10458) Adaptation to long-term forced saline consumption during postweaning in rats. Physiological Psychology, 1973, 1, 185-187.

\section{Sexual and Maternal Behavior}

Barnett, S. A. (Dept. of Zool., Australian National Univ., Canceralia), \& McEwan, I. M. Movements of virgin, pregnant and lactating mice in a residential maze. Physiology \& Behavior, 1973, 10, $741-746$.

Dunlap, J. L. (Tulane Univ., New Orleans, La. 70118), Gerall A. A. \& McLean, L. D. Enhancement of female receptivity in neonatally castrated males by prepuberal ovarian transplants. Physiology \& Behavior, 1973, 10,701.705.

Hendricks, S. E. (Univ. of Nebraska, Omaha, Nebr. 68101), \& Scheetz, H. A. Interaction of hypothalamic structures in the mediation of male sexual behavior Physiology \& Behavior, 1973, 10, 711-716.

Noble, R. G. (Wisconsin Reg. Prim. Rsrch. Ctr., 1223
Capitol Court, Madison. Wis. 53706). Facilitation of the lordosis response of the female hamster (Mesocricetus auratus). Physiology \& Behavior, 1973 . $10,663-666$

\section{Sleep}

Kovalzon, V. M. (N. I. Grashchenkov Lab. for Studying Problems of Control of Functions in Human \& Animal Body, U.S.S.R. Acad. of Sci., Moscow, U.S.S.R.). Brain temperature variations during natural sleep and arousal in white rats. Physiology \& Behavior, 1973, 10, 667-670.

Van Twyver, H., Webb, W. B. (Univ. of Florida, Gainesville, Fla. 32601), Dube, M., \& Zackheim, M. Effects of environmental and strain differences on EEG and behavioral measurement of sleep. Behavioral Biology, 1973, 9, 105-110.

\section{SOCIAL AND ABNORMAL BEHAVIOR}

Beauchamp, G. K. (Monell Chem. Senses Ctr., Univ. of Pennsylvania, Philadelphia, Pa. 19104), \& Berüter, J. Source and stability of attractive components in guinea pig (Cavia porcellus) urine. Behavioral Biology, $1973,9,43 \cdot 47$.

Devor, M. (M.I.T., Cambridge, Mass. 02139), \& Murphy, M. R. The effect of peripheral olfactory blockade on the social behavior of the male golden hamster. Behavioral Biology, 1973, 9, 31-42.

Paul, L. (Temple Univ., Philadelphia, Pa. 19122), Miley, W. M. \& Mazzagatti, N. Social facilitation and inhibition of hunger-induced killing by rats. Journal of Comparative \& Physiological Psychology, 1973, 81, $162-168$

Richardson, E. J., \& Simmel, E. C. (Miami Univ. Oxford, Ohio 45056). Moderation of severity of audiogenic seizures in $\mathrm{DBA} / 2$ mice following intraperitoneal insertion. Bulletin of the Psychonomic Society, 1973, 1, 429-430.

Schulman, A. H. (Virginia Polytech. Inst. \& State Univ., Blacksburg, Va. 24061). Transitivity of social choice: Developmental considerations. Bulletin of the Psychonomic Society, 1973, 1, 425-426.

Wise, L. A. (Univ. of Montana, Missoula, Mont. 59801), Zimmermann, R. R., \& Strobel, D. A. Dominance measurements of low and high protein reared rhesus macaques. Behavioral Biology, 1973, 8, 77-84.

\section{Aggression}

DiMascio, A. (Tufts Univ. Sch. of Med., Boston State Hosp., Boston, Mass. 02124). The effects of benzodiazepines on aggression: Reduced or increased? Psychopharmacologia (Berlin), 1973, 30, 95-102.

Hahn, M. E. (SUNY, Binghamton, N.Y. 13901), Haber, S. B., \& Fuller, J. L. Differential agonistic behavior in mice selected for brain weight. Physiology \& Behavior, 1973, 10, 759-762.

Kesner, R. P. (Univ. of Utah, Salt Lake City, Utah 84112 ), \& Keiser, G. Effects of midbrain reticular lesions upon aggression in the rat. Journal of Comparative \& Physiological Psychology, 1973, 84, 194-206.

Latané, B. (404-C W. 17th Ave., Columbus, Ohio 43201), Edwards, J., Steele, C., \& Walton, D. Social attraction among and between albino and hooded rats. Bulletin of the Psychonomic Society, 1973, 2, 20-22.

Rilling, M. (Michigan State Univ., East Lansing, Mich. 48823), \& Caplan, H. J. Extinction-induced aggression during errorless discrimination learning. Journal of the Experimental Analysis of Behavior, 1973, 20, 85-92. 


\section{SENSORY FUNCTIONS}

Vision

Heaton, M. B. (Div. of Rsrch., North Carolina Dept. of Mental Health, Raleigh, N.C. 27611). Early visual function in bobwhite and Japanese quail embryos as reflected by pupillary reflex. Journal of Comparative \& Physiological Psychology, 1973, 84, 134-139.

Wilkie, D. M. (Univ. of British Columbia, Vancouver, B.C., Canada). Attention and "visual field dependency" in the pigeon. Journal of the Experimental Analysis of Behavior, 1973, 20, 7-15.

\section{Audition}

Amsel, A. (Univ. of Texas, Austin, Tex. 78712), Glazer, H., Lakey, J. R., McCuller, T., \& Wong, P. T. P. Introduction of acoustic stimulation during acquisition and resistance to extinction in the normal and hippocampally damaged rat. Journal of Comparative \& Physiological Psychology, 1973, 84, 176-186.

Popper, A. N. (Dept. Zool. \& Lab. of Sensory Sci., Univ. of Hawaii, Honolulu, Hawaii 96822), \& Fay, R. R. Sound detection and processing by teleost fishes: A critical review. Journal of the Acoustical Society of America, 1973, 53, 1515-1529.

Stitt, C. L., Hoffman, H. S. (Bryn Mawr Coll., Bryn Mawr, Pa. 19010), \& Marsh, R. Modification of the rat's startle reaction by termination of antecedent acoustic signals. Journal of Comparative \& Physiological Psychology, 1973, 84, 207-215.

\section{Lower Senses}

Baran, D. (Univ. of Western Ontario, London 72, Ont., Canada). Responses of male mongolian gerbils to male gerbil odors. Journal of Comparative \& Physiological Psychology, 1973, 84, 63-72.

Beauchamp, G. K. (Monell Chem. Senses Ctr., Univ. of Pennsylvania, Philadelphia, Pa. 19104), \& Berüter, J. Source and stability of attractive components in guinea pig (Cavia porcellus) urine. Behavioral Biology, 1973, 9, 43-47.

Braun, J. J. (Arizona State Univ., Tempe, Ariz. 85281), \& Snyder, D. R. Taste aversions and acute methyl mercury poisoning in rats. Bulletin of the Psychonomic Society, 1973, 1, 419-420.

Devor, M. (Massachusetts Inst. of Tech., Cambridge, Mass. 02139), \& Murphy, M. R. The effect of peripheral olfactory blockade on the social behavior of themale golden hamster. Behavioral Biology, 1973, $9,31-42$.

Sieck, M. H. (Univ. of California, Riverside, Calif. 92502). Selective olfactory system lesions in rats and changes in appetitive and aversive behavior. Physiology \& Behavior, 1973, 10, 731-739.

\section{ANIMAL LEARNING AND RETENTION}

Baum, W. M. (Harvard Univ., Cambridge, Mass. 02138). The correlation-based law of effect. Journal of the Experimental Analysis of Behavior, 1973, 20, 137-153.

Cohen, J. S. (Univ. of Windsor, Windsor 11, Ont., Canada), \& Sullivan, B. Effects of drive level on cue utilization of spatially separated redundant relevant cues. Bulletin of the Psychonomic Society, 1973, 1, 455-457.

Goldberg, M. E. (Squibb Inst. for Med. Rsrch., Princeton, N.J. 08540), Hefner, M. A., Robichaud, R. C ., \& Dubinsky, B. Effects of $\Delta^{9}$-tetrahydrocannabinol (THC) and chlordiazepoxide (CDP) on state-dependent learning: Evidence for asymmetrical dissociation. Psychopharmacologia (Berlin), 1973, 30, 173-184.
Shastiona, V. E. (McLean Hosp. Rsrch. Lab., Dept. of Biol. Chem., Harvard Med. Sch., Belmont, Mass. 02178). Seasonal changes in the learning and activity patterns of goldfish. Science, 1973, 181, 572-574.

Walker, D. W. (VA Hosp., Gainesville, Fla. 32601), \& Means, L. W. Single-alternation performance in rats with hippocampal lesions: Disruption by an irrelevant task interposed during the intertrial interval. Behavioral Biology, 1973, 9, 93-104.

\section{Conditioning}

Bateson, P. P. G. (Sub-Dept. of Anim. Behav., Univ. of Cambridge, Madingley, Cambridge, England), Rose, S. P. R., \& Horn, G. Imprinting: Lasting effects on uracil incorporation into chick brain. Science, 1973, 181, $576-578$

Braun, J. J. (Arizona State Univ., Tempe, Ariz. 85281.), \& Snyder, D. R. Taste aversions and acute methyl mercury poisoning in rats. Bulletin of the Psychonomic Society, 1973, 1, 419-420.

Gaito, J. (York Univ., Downsview, Ont., Canada), \& Hopkins, R. W. Brain soluble protein patterns during shock avoidance conditioning. Bulletin of the Psychonomic Society, 1973, 1, 391-392.

Gilbert, R. M. (Addiction Rsrch. Fndtn., Toronto, Ont., Canada). Keypecking by pigeons in an imperfect environment for authoshaping. Bulletin of the Psychonomic Society, 1973, 2, 10-12.

Hall, R. D. (Rsrch. Lab. of Electronics, M.I.T., Cambridge, Mass. 02139). Some properties of conditioned and unconditioned eyelid reflexes in the albino rat. Behavior Research Methods \& Instrumentation, 1973, 5, 321-331.

Hoffman, H. S. (Bryn Mawr Coll., Bryn Mawr, Pa. 19010), Newby, V., \& Stratton, J. W. Reinforcement of distress vocalization by presentation of an imprinted stimulus. British Journal of Psychology, 1973, 64, 277-282.

Kelly, D. D. (New York State Psychiat. Inst., Dept. of Behav. Physiol., 722 W. 168th St., New York, N.Y. 10032). Long-term prereward suppression in monkeys unaccompanied by cardiovascular conditioning. Journal of the Experimental Analysis of Behavior, 1973, 20, 93-104.

Patterson, M. M., Cegavske, C. F., \& Thompson, R. F (Dept. of Psychobiol., Univ. of California, Irvine, Calif. 92664). Effects of a classical conditioning paradigm on hind-limb flexor nerve response in immobilized spinal cats. Journal of Comparative \& Physiological Psychology, 1973, 84, 88-97.

Powell, R. W. (Univ. of South Florida, Tampa, Fla. 36620). Operant responding in the common crow (Corvus brachyrhynchos). Bulletin of the Psychonomic Society, 1973, 1, 401-403.

Trost, R. C. (Univ. of the South, Sewanee, Tenn. 37375). Differential classical conditioning of abstinence syndrome in morphine-dependent rats. Psychopharmacologia (Berlin), 1973, 30, 153-161.

\section{Discrimination Learning}

Cochrane, T. L. (SUNY, Binghamton, N.Y. 13901), Scobie, S. R., \& Fallon, D. Negative contrast in goldfish (Carassius auratus). Bulletin of the Psychonomic Society, 1973, 1, 411-413.

Coutant, L. W. (Wheaton Coll., Norton, Mass. 02766). Association cortex lesions and stimulus generalization in cats. Physiological Psychology, 1973, 1, 177-180.

Hall, G. (Dalhousie Univ., Halifax, N.S., Canada). Overtraining and reversal learning in the rat: Effects of stimulus salience and response strategies. Journal of Comparative \& Physiological Psychology, 1973, 84, 169-175. 
Hasegawa, Y.. Ibuka, N.. \& Iwahara, S. (Tokyo Univ. of Ed., Tokyo. Japan 112). Effects of chlordiazepoxide upon successive red-green discrimination responses in Japanese monkeys. Macaca fuscata. Psychopharmacologia (Berlin). 1973, 30, 89-94.

Hirota, T. T. (Lniv. of Windsor, Windsor 11, Ont., Canada), \& Clarkson, T. A. Stimulus generalization following intradimensional discrimination training: Between- and within-test comparisons. Bulletin of the Psychonomic Society, 1973, 2, 3-5.

Keyes, J. B. (Lousiana State Univ., Baton Rouge, La. 70803). ECS-produced disruption of a go, n?-go discrimination in rats. Bullet in of the Psychonomic Society, 1973, 1. 439-440.

King, J. E. (Lniv. of Arizona, Tucson, Ariz. 85721). Learning and generalization of a two-dimensional sameness-difference concept by chimpanzees and orangutans. Journal of Comparative \& Physiological Psychology, 1973, 84, 140-148.

Lyons, J. (Univ. of Arizona, Tucson, Ariz. 85721), Klipec, W. D., \& Eirick, R. The effect of chlorpromazine on the peak shift in the albino rat. Physiological Psychology, 1973, 1, 165-168.

Lyons, J. (Univ. of Arizona, Tucson, Ariz. 85721), Klipec, W. D. \& Steinsultz, G. The effect of chlorpromazine on discrimination performance and the peak shift. Physiological Psychology, 1973, 1, $121-124$

Medin, D. L. (Rockefeller Univ., New York, N.Y. 10021). Subproblem analysis of discrimination shift learning. Behavior Research Methods \& Instrumentation, 1973, 5, 332-336.

Miller, L. (Western Washington State Coll., Bellingham, Wash. 98225). Compounding of discriminative stimuli that maintain responding on separate response levers. Journal of the Experimental Analysis of Behavior, $1973,20,57-69$.

Rilling, M. (Michigan State Univ., East Lansing, Mich. 48823), \& Caplan, H. J. Extinction-induced aggression during errorless discrimination learning. Journal of the Experimental Analysis of Behavior, 1973, 20, 85-92.

Saper, C. B. (Washington Univ. Sch. of Med., St. Louis, Mo. 63110), \& Sweeney, D. C. Enhanced appetitive discrimination learning in rats treated with a-methyltyrosine. Psychopharmacologia (Berlin), $1973,30,37-44$.

Sweller, J. (Univ. of Adelaide, Adelaide, South Australia 5001). The effect of task difficulty and criteria of learning on a subsequent reversal. Quarterly Journal of Experimental Psychology, 1973, 25, 223-228.

Vogel, R. (Dept. of Environmental Med., Johns Hopkins Univ., Baltimore, Md. 21205), \& Annau, Z. An operant discrimination task allowing variability of reinforced response patterning. Journal of the Experimental Analysis of Behavior, 1973, 20, 1-6.

Weisinger, R. S. (Univ. of Washington, Seattle, Wash. 98105), Parker, L. F., \& Bolles, R. C. Effects of amount of reward on acquisition of a black-white discrimination. Bulletin of the Psychonomic Society, 1973, 2, 27-28.

Williams, B. A. (Univ. of California, San Diego, La Jolla, Calif. 92037). The failure of stimulus control after presence-absence discrimination of click-rate. Journal of the Experimental Analysis of Behavior, 1973, 20, $23 \cdot 27$.

\section{Maze and Runway Behavior}

Barnett, S. A. (Dept. of Zool., Australian National Univ., Canberra, A.C.T. 2600, Australia), \& McEwan, I. M. Movements of virgin, pregnant and lactating mice in a residential maze. Physiology \& Behavior, 1973, 10, $741-746$.
Hughes, R. N. (Univ. of Canterbury, Christchurch 1, New Zealand). Spontaneous alternation in adult rabbits. Bulletin of the Psychonomic Society, 1973, 2, 2 .

Kilbey, M. M. (Univ. of Houston, 3801 Cullen Blvd., Houston, Tex. 77004), Moore, J. W., Jr., \& Harris, R. $T$. Effects of $\Delta-9$-tetrahydrocannabinol on appetitiveand aggressive-rewarded maze performance in the rat. Physiological Psychology, 1973, 1, 174-176.

Morrison, J. E. (Wake Forest Univ., Winston-Salem, N.C. 27109), Spevack, A. A., \& Yetzierski, R. The effects of response-dependent and response-independent methods on delayed alternation. Behavior Research Methods \& Instrumentation, 1973, 5, 361-363.

Nagy, Z. M. (Bowling Green State Univ., Bowling Green, Ohio 43403). Effect of turn preference upon development of discriminated $\mathrm{T}$-maze training ability of infant mice. Bulletin of the Psychonomic Society, $1973,1,441-442$.

Plotnikoff, N. P. (Div. of Pharmacol. \& Medicinal Chem., Abbott Labs., North Chicago, Ill. 60064). Pemoline: Enhancement of maze performance in young rats. Behavioral Biology, 1973, 8, 117-121.

\section{Avoidance and Punishment}

Badia, P. (Bowling Green State Univ., Bowling Green, Ohio 43403), Coker, C., \& Harsh, J. Choice of higher density signalled shock over lower density unsignalled shock. Journal of the Experimental Analysis of Behavior, 1973, 20, 47-55.

Franchina, J. J. (Virginia Polytech. Inst. \& State Univ., Blacksburg, Va. 24061), Bush, M. E., Kash, J. S., Troen, D. M., \& Young, R. L. Similarity between shock and safe areas during acquisition, transfer, and extinction of escape behavior in rats. Journal of Comparative \& Physiological Psychology, 1973, 84, $216-224$

\section{Avoidance Learning}

Burnstein, D. (c/o Carl Cheney, Utah State Univ., Logan, Utah 84322). Conditioned reinforcement via free-operant avoidance scheduling tests. Bulletin of the Psychonomic Society, 1973, 2, 5-7.

Griffin, P. (Univ. of Alabama, University, Ala. 35486), Medearis, H. D., \& Hughes, W. R. Food deprivation and free-operant avoidance in the pigeon. Bulletin of the Psychonomic Society, 1973, 1, 393-394

Holloway, F. A. (Dept. of Psychiat., Univ. of Oklahoma Health Sci. Ctr., Oklahoma City, Okla. 73190), \& Wansley, R. A. Multiple retention deficits at periodic intervals after active and passive avoidance learning. Behavioral Biology, 1973, 9, 1-14.

James, J. P. (Western Illinois Univ., Macomb, Ill. 61455), Ossenkop, P., \& Mostoway, W. W. Avoidance learning as a function of amount and direction of change in CS intensity without a constant background intensity. Bulletin of the Psychonomic Society, 1973, 2, 18-20.

King, R. A. (Neurobiol. Progr., Univ. of North Carolina, Chapel Hill, N.C. 27514), \& Glasser, R. L. Factors influencing one-trial passive avoidance behavior: Implications for studies of retrograde amnesia (RA). Physiology \& Behavior, 1973, 10,817-819.

Klein, S. B. (Old Dominion Univ., Norfolk, Va. 23508), \& Atkinson, E. J. Mercuric chloride influence on active-avoidance acquisition in rats. Bulletin of the Psychonomic Society, 1973, 1, 437-438

Mellgren, R. L. (Univ. of Oklahoma, Norman, Okla. 73069), Willison, P. W., \& Dickson, A. L. Acquisition of passive avoidance in rats. Bulletin of the Psychonomic Society, 1973, 2, 37-38.

Sherrod, K. B. (Fisk Univ., Nashville, Tenn. 37203). Effects of irradiation and/or handling on shuttle box 
performance of $\mathrm{C} 57 \mathrm{Bl} / 6$ mice. Physiology \& Behavior, $1973,10,721 \cdot 724$.

\section{Punishment}

Hull, J. H. (Kent State Univ., Kent, Ohio 44242), \& Klugh, H. E. Recovery from punishment related to movement and punishment severity. Bulletin of the Psychonomic Society, 1973, 1, 406-408.

MacDonald, L. (Wedgie's Sandwich House, $4871 \mathrm{~N}$. Green Bay Ave., Milwaukee, Wis. 53209). The relative aversiveness of signalled versus unsignalled shock-punishment. Journal of 'the Experimental Analysis of Behavior, 1973, 20, 37-46.

McMillan, D. E. (Dept. of Pharmacol., Sch. of Med., Univ. of North Carolina, Chapel Hill, N.C. 27514). Drugs and punished responding. III. Punishment intensity as a determinant of drug effect. Psychopharmacologia (Berlin), 1973, 30, 61-74.

\section{Reinforcement}

Bushnell, P. J. (Reg. Prim. Rsrch. Ctr., Univ. of Wisconsin, Madison, Wis. 53706), Henry, K. R., \& Bowman, R. E. The intercalated reinforcement technique: Learning without differential total reinforcement between groups. Behavior Research Methods \& Instrumentation, 1973, 5, 337-339.

Henke, P. G. (St. Francis Xavier Univ., Antigonish, N.S., Canada). Effects of reinforcement omission on rats with lesions in the amygdala. Journal of Comparative \& Physiological Psychology, 1973, 84, 187-193.

Kelly, D. D. (New York State Psychiat. Inst., Dept. of Behav. Physiol., 722 W. 168th St., New York, N.Y. 10032). Long-term prereward suppression in monkeys unaccompanied by cardiovascular conditioning. Journal of the Experimental Analysis of Behavior, $1973,20,93-104$

Kendall, S. B. (Univ. of Western Ontario, London 72 , Ont., Canada). Effects of two procedures for varying information transmission on observing responses. Journal of the Experimental Analysis of Behavior, $1973,20,73-83$.

Mandler, J. M. (Univ. of California, San Diego, La Jolla, Calif. 92037), \& Goldberg, J. Effects of partially and continuously reinforced pretraining on choice and latency measures in the rat. Journal of Comparative \& Physiological Psychology, 1973, 84, 118-127.

Vogel, R. (Dept. of Environmental Med., Johns Hopkins Univ., Baltimore, Md. 21205), \& Annau, Z. An operant discrimination task allowing variability of reinforced response patterning. Journal of the Experimental Analysis of Behavior, 1973, 20, 1-6.

Weisinger, R. S. (Univ. of Washington, Seattle, Wash. 98105), Parker, L. F., \& Bolles, R. C. Effects of amount of reward on acquisition of a black-white discrimination. Bulletin of the Psychonomic Society 1973, 2, 27-28.

\section{Schedules of Reinforcement}

Balster, R. L. (Dept. of Psychiat., Duke Univ., Durham, N.C. 27710), \& Schuster, C. R. Fixed-interval schedule of cocaine reinforcement: Effect of dose and infusion duration. Journal of the Experimental Analysis of Behavior, 1973, 20, 119-129.

Bitgood, S. C. (McMaster Univ., Hamilton, Ont., Canada), \& Platt, J. R. Effects of reinforcement duration and ratio size on discrete-trials FR responding. Bulletin of the Psychonomic Society, 1973, 1, 409-411.

Burnstein, D. (c/o Carl Cheney, Utah State Univ., Logan, $\mathrm{Utah} 84322$ ). Conditioned reinforcement via free-operant avoidance scheduling tests. Bulletin of the Psychonomic Society, 1973, 2, 5-7

Dougherty, J. (VA Hosp., Lexington, Ky. 40507), \& Pickens, R. Fixed-interval schedules of intravenous cocaine presentation in rats. Journal of the Experimental Analysis of Behavior, 1973, 20, 111.118

Grossmann, K. E. (Pädagogische Hochschule Westfalen-Lippe, Lampingstrasse 3, 48, Bielefeld, West Germany). Continuous, fixed-ratio, and fixed-interval reinforcement in honey bees. Journal of the Experimental Analysis of Behavior, 1973, 20, 105-109.

Peters, R. H. (Iowa State Univ., Ames, Iowa 50010), Sensenig, L. D., \& Reich, M. J. Fixed-ratio performance following ventromedial hypothalamic lesions in rats. Physiological Psychology, 1973, 1 136-138

Pierson, S. C. (Dept. of Ecol. \& Behav. Biol., Univ. of Minnesota, St. Paul, Minn. 55101), \& Schaeffer, R. W. Differential reinforcement of specific lick rates in the rat. Bulletin of the Psychonomic Society, 1973, 2, 31-34

Schwartz, B. (Swarthmore Coll., Swarthmore, Pa. 19081). Maintenance of key pecking by response-independent food presentation: The role of the modality of the signal for food. Journal of the Experimental Analysis of Behavior, 1973, 20, 17-22.

Wilkie, D. M. (Univ. of British Columbia, Vancouver, B.C., Canada). Signalled reinforcement in multiple and concurrent schedules. Journal of the Experimental Analysis of Behavior, 1973, 20, 29-36.

\section{Extinction}

Amsel, A. (Univ. of Texas, Austin, Tex. 78712), Glazer, H., Lakey, J. R., McCuller, R., \& Wong, P. T. P. Introduction of acoustic stimulation during acquisition and resistance to extinction in the normal and hippocampally damaged rat. Journal of Comparative \& Physiological Psychology, 1973, 84, 176-186.

Stratton, L. O. (Louisiana State Univ., New Orleans, La. 70122), \& Kastin, A. J. Melanocyte stimulating hormone in learning and extinction of two problems. Physiology \& Behavior, 1973, 10, 689-692.

\section{Retention}

Bliss, D. K. (SUNY, Binghamton, Binghamton, N.Y. 13901). Dissociated learning and state-dependent retention induced by pentobarbital in rhesus monkeys. Journal of Comparative \& Physiological Psychology, 1973, 84, 149-161.

David-Remacle, M. (Centre de Psychologie, Experimentale et Comparée, Université Catholique de Louvain, Chateau de Pellenberg, Belgium). Attenuation of anoxia-induced retrograde amnesia in rats by a pretraining placebo injection. Physiology \& Behavior, 1973, 10, 693-696.

Haycock, J. W. (Dept. of Psychobiol., Sch. of Biol. Sci., Univ. of California, Irvine, Calif. 92664), \& McGaugh, J. L. Retrograde amnesia gradients as a function of ECS-intensity. Behavioral Biology, 1973, 9, 123-127.

Hinderliter, C. F., Smith, S. L., \& Misanin, J. R. (Susquehanna Univ., Selinsgrove, Pa. 17870). Effects of pretraining experience on retention of a passive avoidance task following ECS. Physiology \& Behavior, $1973,10,671-675$.

Holloway, F. A. (Dept. of Psychiat., Univ. of Oklahoma Hlth. Sci. Ctr., Oklahoma City, Okla. 73190), \& Wansley, R. A. Multiple retention deficits at periodic intervals after active and passive avoidance learning. Behavioral Biology, 1973, 9, 1-14. 
Johnson, D. M.. \& Platt. J. R. (McMaster Univ., Hamilton, Ont., Canada). Short-term retention of location within a homogeneous behavior sequence in rats. Journal of Comparative \& Physiological Psychology, 1973, 84, 111-117.

King, R. A. (Neurobiol. Progr., Univ. of North Carolina, Chapel Hill, N.C. 27514), \& Glasser, R. L. Factors influencing one-trial passive avoidance behavior: Implications for studies of retrograde amnesia (RA). Physiology \& Behavior, 1973, 10, 817-819.

Marriott, J. G. (Univ. of Colorado, Boulder, Colo. 80302), \& Alpern, H. P. An analysis of the time-dependent aspect of short-term memory in mice. Behavioral Biology, 1973, 9, 85-91.

Routtenberg, A. (Cresap Lab. of Neurosci. \& Behav., Northwestern Univ., Evanston, Ill. 60201), \& Holzman, N. Memory disruption by electrical stimulation of substantia nigra, pars compacta. Science, 1973, 181, 83-86.

Spiliotis, P. H. (Lousiana State Univ., Baton Rouge, La. 70803 ), \& Thompson, $R$. The "manipulative response memory system" in the white rat. Physiological Psychology, 1973, 1, 101-114.

Van Abeelen, J. (Genetics Lab., Univ. of Nijmegen, Driehuizerweg 200, Nijmegen, The Netherlands), Daems, J., \& Douma, G. Memory storage in three inbred mouse strains after injection of cycloheximide. Physiology \& Behavior, 1973, 10, 751-753.

Zornetzer, S. F. (Dept. of Neurosci., Coll. of Med., Univ. of Florida, Gainesville, Fla. 32601), \& Chronister, R. B. Neuroanatomical localization of memory disruption: Relationship between brain structure and learning task. Physiology \& Behavior, 1973, 10, 747-750.

\section{PHYSIOLOGICAL PSYCHOLOGY}

Beaubaton, D. (Département de Psychophysiologie Générale. Institut de Neurophysiologie et Psychophysiologie, C.N.R.S., Marseille, France), \& Requin, J. The time course of preparatory processes in split-brain monkeys performing a variable foreperiod reaction time task. Physiology \& Behavior, $1973,10,725-730$.

Braud, W. G. (Univ. of Houston, Houston, Tex. 77004), \& Hoffman, R. B. Response facilitation and response inhibition produced by intracranial injections of brain extracts from trained donor goldfish. Physiological Psychology, 1973, 1, 169-173.

Dubuc, P. U. (Dept. of Metabolism \& Endocrinol., City of Hope National Med. Ctr., Duarte, Calif. 91010), \& Reynolds, R. W. Hypothalamic metallic deposition and the production of experimental obesity. Physiology \& Behavior, 1973, 10,677-681.

Hahn, M. E. (SUNY, Binghamton, N.Y. 13901), Haber, S. B., \& Fuller, J. L. Differential agonistic behavior in mice selected for brain weight. Physiology \& Behavior, 1973, 10, 759-762.

Huston, J. P. (Inst. of Pharmacol., Univ. of Zürich, Gloriastrasse 32, Zürich, Switzerland), \& Bureš, J. Effects of cortical spreading depression on behaviors elicited by hypothalamic stimulation in rats. Physiology \& Behavior, 1973, 10, 775-780.

Kovalzon, V. M. (N. I. Grashchenkov Lab. for Studying Problems of Control of Functions in Human \& Anim. Body, U.S.S.R. Acad. of Sci., Moscow, U.S.S.R.). Brain temperature variations during natural sleep and arousal in white rats. Physiology \& Behavior, 1973, $10,667-670$.

\section{Lesions}

Amsel, A. (Univ. of Texas, Austin, Tex. 78712), Glazer, H., Lakey, J. R., McCuller, T., \& Wong, P. T. P. Introduction of acoustic stimulation during acquisition and resistance to extinction in the normal and hippocampally damaged rat. Journal of Comparative \& Physiological Psychology, 1973, 84, 176-186

Coutant, L. W. (Wheaton Coll., Norton, Mass. 02766). Association cortex lesions and stimulus generalization in cats. Physiological Psychology, 1973, 1, 177-180.

Divac, I. (Inst. of Neurophysiol., Lab. of Behav. Physiol., 36, Juliane Maries Vej, DK-2100, Copenhagen, Denmark). Delayed response in cats after frontal lesions extending beyond the gyrus proreus. Physiology \& Behavior, 1973, 10, 717-720.
Fried, P. A. (Carleton Univ., Ottawa, Canada). The septum and hyper-reactivity: A review. British Journal of Psychology, 1973, 64, 267-275.

Kesner, R. P. (Univ. of Utah, Salt Lake City, Utah $84112)$, \& Keiser, G. Effects of midbrain reticular lesions upon aggression in the rat. Journal of Comparative \& Physiological Psychology, 1973, 84, 194-206.

Spiliotis, P. H. (Louisiana State Univ., Baton Rouge, La. 70803), \& Thompson, R. The "manipulative response memory system" in the white rat. Physiological Psychology, 1973, 1, 101-114.

Walker, D. W. (VA Hosp., Gainesville, Fla. 32601), \& Means, L. W. Single-alternation performance in rats with hippocampal lesions: Disruption by an irrelevant task interposed during the intertrial interval. Behavioral Biology, 1973, 9, 93-104.

Ward, J. E. (California State Univ., Sacramento, Calif. 95819), \& Doolittle, J. H. The effect of the anterior ganglia on forward movements in the earthworm. Physiological Psychology, 1973, 1, 129-132.

\section{A mygdala}

Czech, D. A. (Marquette Univ., Milwaukee, Wis. 53233). Effects of amygdalar lesions on eating and drinking and saline preference in the rat. Physiology \& Behavior, 1973, 10, 821-823.

Henke, P. G. (St. Francis Xavier Univ., Antigonish, N.S., Canada). Effects of reinforcement omission on rats with lesions in the amygdala. Journal of Comparative \& Physiological Psychology, 1973, 84, 187-193.

Henke, P. G. (St. Francis Xavier Univ., Antigonish, N.S., Canada), \& Maxwell, D. Lesions in the amygdala and the frustration effect. Physiology \& Behavior, 1973, $10,647-650$

\section{Hypothalamus}

Harrell, E. H. (North Texas State Univ., Denton, Tex. 76201), \& Remley, N. R. The immediate development of behavioral and biochemical changes following ventromedial hypothalamic lesions in rats. Behavioral Biology, 1973, 9, 49-63.

Hendricks, S. E. (Univ. of Nebraska, Omaha, Nebr. $68101)$, \& Scheetz, H. A. Interaction of hypothalamic structures in the mediation of male sexual behavior. Physiology \& Behavior, 1973, 10, 711-716.

Jaffe, M. L. (Adelphi Univ., Garden City, N.Y. 11530). The effects of lesions in the ventromedial nucleus of the hypothalamus on behavioral contrast in rats. Physiological Psychology, 1973, 1, 191-198. 
Keesey, R. E. (Univ. of Wisconsin, Madison, Wis. 53706), \& Boyle, P. C. Effects of quinine adulteration upon body weight of LH-lesioned and intact male rats. Journal of Comparative \& Physiological Psychology, 1973, 84, 38-46.

Kristal, M. B. (Jackson Lab., Bar Harbor, Maine 04609). Effects of lateral hypothalamic lesions on placentophagia in virgin, primiparous, and multiparous rats. Journal of Comparative \& Physiological Psychology, 1973, 84, 53-62.

Panksepp, J. (Bowling Green State Univ., Bowling Green, Ohio 43403). The ventromedial hypothalamus and metabolic adjustments of feeding behavior. Behavioral Biology, 1973, 9, 65-75.

Peters, R. H. (Iowa State Univ., Ames, Iowa 50010), Sensenig, L. D., \& Reich, M. J. Fixed-ratio performance following ventromedial hypothalamic lesions in rats. Physiological Psychology, 1973, 1, $136-138$.

Singh, D. (Univ. of Texas, Austin, Tex. 78712). Effects of preoperative training on food-motivated behavior of hypothalamic hyperphagic rats. Journal of Comparative \& Physiological Psychology, 1973, 84, 47-52.

\section{Stimulation}

Blum, B. (Depts. of Physiol. \& Pharmacol., Tel-Aviv Univ. Med. Sch., Tel-Aviv, Israel), \& Segal, R. Modifications in cortically-induced peripheral motor nerve activity induced by the center median in the cat and in the squirrel monkey. Physiology \& Behavior, $1973,10,755-758$

Blundell, J. E. (Univ. of Leeds, Leeds, LS2 9JT, England), \& Herberg, L. J. Effectiveness of lateral hypothalamic stimulation, arousal, and food deprivation in the initiation of hoarding behaviour in naive rats. Physiology \& Behavior, 1973, 10, 763-767.

Carmona, A. (Departamento de Fisiologia y Biofisica, Facultad de Medicina, Universidad de Chile, Casilla 6524, Santiago, Chile), \& Slangen, J. Effects of chemical stimulation of the hypothalamus upon gastric secretion. Physiology \& Behavior, 1973, 10, 657-661.

Latash, L. P. (N. I. Grashchenkov Lab. for Studying Problems of Control of Functions in Human \& Anim. Body, U.S.S.R. Acad. of Sci., Moscow, U.S.S.R.), \& Kovalzon, V. M. LHA self-stimulation effects on EEG and brain temperature in white rats. Physiology \& Behavior, 1973, 10, 651-655.

Mendelson, J. (Univ. of Kansas, Lawrence, Kans. 66044), \& Maul, G. Effects of hypothalamic current intensity on object carrying induced by shuttlebox self-stimulation in rats. Physiological Psychology, $1973,1,181-184$

Routtenberg, A. (Cresap Lab. of Neurosci. \& Behav., Northwestern Univ., Evanston, Ill.), \& Holzman, N. Memory disruption by electrical stimulation of substantia nigra, pars compacta. Science, 1973, 181, 83-86.

Steiner, S. S. (City Coll. of CUNY, New York, N.Y. 10010), \& Stokely, S. N. Methamphetamine lowers self-stimulation thresholds. Physiological Psychology, $1973,1,161-164$.

Wauquier, A. (Dept. of Pharmacol., Janssen Pharmaceutica, Rsrch. Lab., B-2340 Beerse, Belgium), \& Niemegeers, C. J. E. Intracranial self-stimulation in rats as a function of various stimulus parameters. III. Influence of apomorphine on medial forebrain bundle stimulation with monopolar electrodes. Psychopharmacologia (Berlin), 1973, 30, 163-172.

Zornetzer, S. F. (Dept. of Neurosci.. Coll. of Med., Univ. of Florida, Gainesville, Fla. 32601), \& Chronister, R. B. Neuroanatomical localization of memory disruption: Relationship between brain structure and learning task. Physiology \& Behavior, 1973, 10, $747 \cdot 750$.

\section{Electroconvulsive Shock}

Haycock, J. W. (Dept. of Psychobiol., Sch. of Biol. Sci., Univ. of California, Irvine, Calif. 92664), \& McGaugh, J. L. Retrograde amnesia gradients as a function of ECS-intensity. Behavioral Biology, 1973, 9, 123-127.

Hinderliter, C. F., \& Misanin, J. R. (Susquehanna Univ., Selinsgrove, $\mathrm{Pa}$. 17870). A note on the visual cliff behavior of rats following ECS. Physiological Psychology, 1973, 1, 139-140.

Hinderliter, C. F., Smith, S. L., \& Misanin, J. R. (Susquehanna Univ., Selinsgrove, Pa. 17870). Effects of pretraining experience on retention of a passive avoidance task following ECS. Physiology \& Behavior, $1973,10,671-675$.

Keyes, J. B. (Louisiana State Univ., Baton Rouge, La. 70803). ECS-produced disruption of a go, no-go discrimination in rats. Bulletin of the Psychonomic Society, 1973, 1, 439-440.

Keyes, J. B. (Lousiana State Univ., Baton Rouge, La. 70803), \& Dempsey, G. L. The effect of motivational states on ECS-induced perseveration. Physiological Psychology, 1973, 1, 133-135.

\section{Electrical Activity}

Andreassi, J. L. (New York Univ., Bronx, N.Y. 10453), Mayzner, M. S., Stern, M., \& Okamura, H. Visual cortical evoked potentials under conditions of apparent motion. Physiological Psychology, 1973, 1, 118-120.

Bridge, J. G. (Michigan State Univ., East Lansing, Mich. 48823), \& Hatton, G. I. Septal unit activity in response to alterations in blood volume and osmotic pressure. Physiology \& Behavior, 1973, 10, 769-774.

Corby, J. C. (c/o Dr. Bert S. Kopell, Dept. of Psychiat., Stanford Univ. Sch. of Med., Stanford, Calif. 94305), \& Kopell, B. S. The effect of predictability on evoked response enhancement in intramodal selective attention. Psychophysiology, 1973, 10, 335-346.

Ford, J. M. (Dept. of Psychiat., Stanford Univ. Sch. of Med., Stanford, Calif. 94305), Roth, W. T., Dirks, S. J., \& Kopell, B. S. Evoked potential correlates of signal recognition between and within modalities. Science, 1973, 181, 465-566.

Latash, L. P. (N. I. Grashchenkov Lab. for Studying Problems of Control of Functions in Human \& Anim. Body, U.S.S.R. Acad. of Sci., Moscow, U.S.S.R.), \& Kovalzon, V. M. LHA self-stimulation effects on EEG and brain temperature in white rats. Physiology \& Behavior, 1973, 10, 651-655.

Lelord, G. (Neurophysiol. \& Exptl. Psychopathol. Lab., Faculté de Médecine, Tours, France), Laffont, F.. Jusseaume, P., \& Stephant, J. L. Comparative study of conditioning of averaged evoked responses by coupling sound and light in normal and autistic children. Psychophysiology, 1973, 10, 415-425.

McAdam, D. W. (Univ. of Rochester, Rochester, N.Y. $14627)$. Scaled lateralization of alpha activity during linguistic and musical tasks. Psychophysiology, 1973, $10,441-443$

Paskewitz, D. A. (Unit for Exptl. Psychiat., Inst. of the Pennsylvania Hosp., 111 N. 49th St., Philadelphia, Pa. 19139), \& Orne, M. T. Visual effects on alpha feedback training. Science, 1973, 181, 360-363.

Schechter, G., \& Buchsbaum, M. (NIMH, Bldg. 10, Rm. 2N-315, Bethesda, Md. 20014). The effects of 
attention, stimulus intensity, and individual differences on the average evoked response. Psychophysiology, 1973, 10, 392-400.

Stowell, H. (Rsrch. Dept., Central State Hosp., Milledgeville, Ga. 31062). Averaged evoked responses to tapping: A one-subject scalp study of large signals. Psychophysiology, 1973, 10, 383-391.

Van Twyver, H., Webb, W. B. (Univ. of Florida, Gainesville, Fla. 32601), Dube, M., \& Zackheim, M. Effects of environmental and strain differences on EEG and behavioral measurement of sleep. Behavioral Biology, 1973, 9, 105-110.

\section{Metabolism}

Bateson, P. P. G. (Sub-Dept. of Anim. Behav., Univ. of Cambridge, Madingley, Cambridge, England), Rose, S. P. R., \& Horn, G. Imprinting: Lasting effects on uracil incorporation into chick brain. Science, 1973, 181, 576-578.

Carlsson, A. (Dept. of Pharmacol., Univ. of Göteborg, Göteborg, Sweden), Magnusson, T., Svensson, T. H., \& Waldeck, B. Effect of ethanol on the metabolism of brain catecholamines. Psychopharmacologia (Berlin), 1973, 30, 27-36.

Gaito, J. (York Univ., Downsview, Ont., Canada), \& Hopkins, R. W. Brain soluble protein patterns during shock avoidance conditioning. Bulletin of the Psychonomic Society, 1973, 1, 391-392.

Sheard, M. H. (Dept. of Psychiat., Yale Univ. Sch. of Med., New Haven, Conn. 06519). Brain serotonin depletion by p-chlorophenylalanine or lesions of raphe neurons in rats. Physiology \& Behavior, 1973, $10,809-811$.

\section{PHYSIOLOGICAL EFFECTS}

Grimsley, D. L. (Univ. of North Carolina, Charlotte, N.C. 28213). Carotid ligation in the rat. Physiological Psychology, 1973, 1, 147-148.

Spiegel, T. A. (Univ. of Pennsylvania, Philadelphia, Pa. 19104). Caloric regulation of food intake in man. Journal of Comparative \& Physiological Psychology, 1973, 84, 24-37.

Wise, L. A. (Univ. of Montana, Missoula, Mont. 59801), Zimmermann, R. R., \& Strobel, D. A. Dominance measurements of low and high protein reared rhesus macaques. Behavioral Biology, 1973, 8, 77-84.

\section{Biochemical Effects}

Falk, J. L. (Rutgers Univ., New Brunswick, N.J. 08903), \& Tang, M. Nonuremic hyperosmolality produced by sodium depletion. Physiology \& Behavior, 1973, 10, 793-799.

Harrell, E. H. (North Texas State Univ., Denton, Tex. 76201 ), \& Remley, N. R. The immediate development of behavioral and biochemical changes following ventromedial hypothalamic lesions in rats. Behavioral Biology, 1973, 9, 49-63.

Turnbull M. J. (Dept. of Pharmacol. \& Therapeutics, Univ. of Dundee, Dundee, Scotland), \& Ballinger, B. $R$. Urinary excretion of monoamines and metabolites in patients dependent on and withdrawn from barbiturates. Psychopharmacologia (Berl.), 1973, 30, 103-108.

\section{Hormonal Effects}

Dunlap, J. L. (Tulane Univ., New Orleans, La. 70118), Gerall, A. A., \& McLean, L. D. Enhancement of female receptivity in neonatally castrated males by prepuberal ovarian transplants. Physiology \& Behavior, 1973, 10, 701-705.

Krecék, J. (Inst. of Physiol., Czechoslovak Acad. of Sci.,
Prague, Czechoslovakia). Sex differences in salt taste: The effect of testosterone. Physiology \& Behavior, $1973,10,683-688$.

Ley, K. F. (Univ. of Vermont, Burlington, Vt. 05401), \& Corson, J. A. Effects of ACTH, adrenalectomy and time of day on emotional activity of the rat. Behavioral Biology, 1973, 9, 111-115.

Shashova, V. E. (McLean Hosp. Rsch. Lab., Dept. of Biol. Chem., Harvard Med. Sch., Belmont, Mass. 02178). Seasonal changes in the learning and activity patterns of goldfish. Science, 1973, 181, 572-574.

Stratton, L. O. (Louisiana State Univ., New Orleans, La. 70122), \& Kastin, A. J. Melanocyte stimulating hormone in learning and extinction of two problems. Physiology \& Behavior, 1973, 10, 689-692.

\section{Drug Effects}

Agué, C. (Inst. of Psychiat., London, England). Smoking patterns, nicotine intake at different times of day and changes in two cardiovascular variables while smoking cigarettes. Psychopharmacologia (Berl.), 1973, 30, 135-144.

Angrist, B. (Neuropsychopharmacol. Rsch. Unit, Dept. of Psychiat., New York Univ. Med. Ctr., New York, N.Y. 10016), \& Gershon, S. Behavioral profile of a potent new psychotoxic compound. Psychopharmacologia (Berl.), 1973, 30, 109-116.

Bliss, D. K. (SUNY, Binghamton, N.Y. 13901). Dissociated learning and state-dependent retention induced by pentobarbital in rhesus monkeys. Journal of Comparative \& Physiological Psychology, 1972, 84, 149-161.

Belenko, S. (Columbia Univ., New York, N.Y. 10027), \& Woods, S. C. Physiological correlates of ethanol self-selection by rats. Physiological Psychology, 1973, 1, 155-157.

Carlsson, A. (Dept. of Pharmacol., Univ. of Göteborg, Göteborg, Sweden), Magnusson, T., Svensson, T. H., $\&$ Waldeck, B. Effect of ethanol on the metabolism of brain catecholamines. Psychopharmacologia (Berl.), $1973,30,27-36$.

DiMascio, A. (Tufts Univ. Sch. of Med., Boston State Hosp., Boston, Mass. 02124). The effects of benzodiazepines on aggression: Reduced or increased? Psychopharmacologia (Berl.), 1973, 30, 95-102.

Goldberg, M. E. (Squibb Inst. for Med. Rsch., Princeton, N.J. 08540), Hefner, M. A., Robichaud, R. C., \& Dubinsky, B. Effects of $\Delta^{9}$-tetrahydrocannabinol (THC) and chlordiazeposide (CDP) on state-dependent learning: Evidence for asymmetrical dissociation. Psychopharmacologia (Berl.), 1973, 30, 173-184.

Hasegawa, Y., Ibuka, N., \& Iwahara, S. (Tokoyo Univ. of Ed., Tokyo, Japan 112). Effects of chlordiazepoxide upon successive red-green discrimination responses in Japanese monkeys, Macaca fuscata. Psychopharmacologia (Berl.), 1973, 30, 89-94.

Jones, B. E. (Natl. Inst. of Mental Health, Addiction Rsch. Ctr., Lexington, Ky. 40507), \& Prada, J. A. Relapse to morphine use in dog. Psychopharmacologia (Berl.), 1973, 30, 1-12.

Keesey, R. E. (Univ. of Wisonsin, Madison, Wis. 53706), \& Boyle, P. C. Effects of quinine adulteration upon body weight of LH-lesioned and intact male rats. Journal of Comparative \& Physiological Psychology, $1973,84,38-46$.

Khavari, K. A. (Univ. of Wisconsin, Milwaukee, Wis. 53201 ), \& Risner, M. E. Concentration-ingestion relations of morphine-adulterated food and morphine solution. Psychopharmacologia (Berl.), 1973, 30, 45-60. 
Kilbey, M. M. (Univ. of Houston, 3801 Cullen Blvd., Houston, Tex. 77004), Moore, J. W., Jr., \& Harris, R. T. Effects of $د^{9}$-tetrahydrocannabinol on appetitiveand aggressive-rewarded maze performance in the rat. Physiological Psychology, 1973, 1, 174-176.

Klein, S. B. (Old Dominion Univ., Norfilk, Va. 23508), \& Atkinson, E. J. Mercuric chloride influence on active-avoidance acquisition in rats. Bulletin of the Psychonomic Society, 1973, 1, 437-438.

Konzett, H. (Pharmakologisches Institut der Universität Innsbruck, Innsbruck, Austria), Berner, W., \& Lochs, H. Emotionally induced cardiovascular changes in man as a means for the investigation of tranquilling drugs. Psychopharmacologia (Berl.), 1973, 30, 75-82.

LeBlanc, A. E. (Dept. of Pharmacol., Univ. of Toronto, Toronto, Ont., Canada), Gibbins, R. J., \& Kalant, H. Behavioral augmentation of tolerance to ethanol in the rat. Psychopharmacologia (Berl.), 1973, 30, 117-122.

Lyons, J. (Univ. of Arizona, Tucson, Ariz. 85721), Klipec, W. D., \& Eirick, R. Physiological Psychology, 1973, 1, 165-168.

Lyons, J. (Univ. of Arizona, Tucson, Ariz. 85721), Klipec, W. D., \& Steinsultz, G. The effect of chlorpromazine on discrimination performance and the peak shift. Physiological Psychology, 1973, 1, 121-124.

McMillan, D. E. (Dept. of Pharmacol., Sch. of Med., Univ. of North Carolina, Chapel Hill, N.C. 27514). Drugs and punished responding. III. Punishment intensity as a determinant of drug effect. Psychopharmacologia (Berl.), 1973, 30, 61-74.

Modigh, K. (Dept. of Pharmacol., Univ. of Göteborg, Göteborg, Sweden). Effects of L-tryptophan on motor activity in mice. Psychopharmacologia (Berl.), 1973, 30, 123-134.

Plotnikoff, N. P. (Div. of Pharmacol. \& Med. Chem., Abbott Labs., North Chicago, Ill. 60064). Pemoline: Enhancement of maze performance in young rats. Behavioral Biology, 1973, 8, 117-121.

Saper, C. B. (Washington Univ. Sch. of Med., St. Louis, Mo. 63110), \& Sweeney, D. C. Enhanced appetitive discrimination learning in rats treated with $\alpha$-methyltyrosine. Psychopharmacologia (Berl.), 1973, $30,37-44$.

Sheard, M. H. (Dept. of Psychiat., Yale Univ. Sch. of Med., New Haven, Conn. 06519). Brain serotonin depletion by p-chlorophenylalanine of lesions of raphe neurons in rats. Physiology \& Behavior, 1973, 10, 809-811.

Smith, D. F. (Psychopharmacol. Rsch. Univ., Statshospitalet, 8240 Risskov, Denmark), \& Smith, H. $B$. The effect of prolonged lithium administration on activity, reactivity, and endurance in the rat. Psychopharmacologia (Berl.), 1973, 30, 83-88.

Sofia, R. D. (Dept. of Pharmacol., Wallace Labs., Cranbury, N.J. 08512), \& Knobloch, L. C. The interaction of $\Delta^{9}$-tetrahydrocannabinol pretreatment with various sedative-hypotic drugs. Psychopharmacologia (Berl.), 1973, 30, 185-194.

Steiner, S. S. (City Coll. of CUNY, New York, N.Y. 10010), \& Stokely, S. N. Methamphetamine lowers self-stimulation thresholds. Physiological Psychology, 1973, 1, 161-164.

Trost, R. C. (Univ. of the South, Sewanee, Tenn. 37375). Differential classical conditioning of abstinence syndrome in morphine-dependent rats. Psychopharmacologia (Berl.), 1973, 30, 153-161.

Turnbull, M. J. (Dept. of Pharmacol. \& Therapeutics, Univ. of Dundee, Dundee. Scotland), \& Ballinger, B.
R. Urinary excretion of monoamines and metabolites in patients dependent on and withdrawn from barbiturates. Psychopharmacologia (Berl.), 1973, 30, $103-108$.

Van Abeelen, J. (Genetics Lab., Univ. of Nijmegen, Driehuizerweg 200, The Netherlands), Daems, J., \& Douma, G. Memory storage in three inbred mouse strains after injection of cycloheximide. Physiology \& Behavior, 1973, 10, 751-753.

Vaupel, D. B. (Natl. Inst. of Mental Health, Addiction Rsch. Ctr., Lexington, Ky. 40507), \& Martin, W. R. Interaction of oxotremorine with atropine, chlorpromazine, cyproheptadine, imipramine and phenoxybenzamine on the flexor reflex of the chronic spinal dog. Psychopharmacologia (Berl.), 1973, 30, 13-26.

Vogel, W. H. (Dept. of Pharmacol., Thomas Jefferson Univ., Jefferson Med. Coll., Phildelphia, Pa. 19107), Evans, B. D., Bonnem, E. M., \& Fischer, J. F. M a cromerine, normacromerine and bisnormacromerine: Non-psychoactive methylated derivatives of norepinephrine. Psychopharmacologia (Berl.), 1973, 30, 145-151.

Wauquier, A. (Dept. of Pharmacol., Janssen Pharmaceutica, Rsch. Lab., B-2340 Beerse, Belgium), \& Niemegeers, C. J. E. Intracranial self-stimulation in rats as a function of various stimulus parameters. Psychopharmacologia (Berl.), 1973, 30, 163-172.

\section{Stress Effects}

Hamilton, L. W. (Rutgers Univ., New Brunswick, N.J. 08903), \& Katske, F. A. Rapid gastric ulceration in a modified two-way shuttlebox. Physiological Psychology, 1973, 1, 188-190.

Mason, J. W. (Dept. of Neuroendocrinol., Walter Reed Army Inst. of Rsch., Walter Reed Army Med. Ctr., Washington, D.C. 20012), Mougey, E. H., \& Kenion, C. C. Urinary epinephrine and norepinephrine responses to chair restraint in the monkey. Physiology \& Behavior, 1973, 10, 801-804.

Wald, E. D. (Univ. of Denver, Denver, Colo. 80210), MacKinnon, J. R., \& Desiderato, O. Production of gastric ulcers in the unrestrained rat. Physiology \& Behavior, 1973, 10, 825-827.

\section{Autonomic Effects}

Furedy, J. J. (Univ. of Toronto, Toronto 181, Ont., Canada), \& Ginsberg, S. Effects of varying signaling and intensity of shock on an unconfounded and novel electrodermal autonomic index in a variable and long-interval classical trace conditioning paradigm. Psychophysiology, 1973, 10, 328-334.

Graham, F. K. (Univ. Hospitals, Madison, Wis. 53706), \& Slaby, D. A. Differential heart rate changes to equally intense white noise and tone. Psychophysiology, $1973,10,347-362$.

Grings, W. W. (Univ. of Southern California, University Park, Los Angeles, Calif. 90007), Schell, A. M., \& Carey, C. A. Verbal control of an autonomic response in a cue reversal situation. Journal of Experimental Psychology, 1973, 99, 215-221.

Kazis, E., Milligan, W. L., \& Powell, D. A. (Neurosci. Lab., VA Hosp., Columbia, S.C. 29201). Autonomic-somatic relationships: Blockade of heart rate and corneo-retinal potential responses. Journal of 
Comparative \& Physiological Psychology, 1973, 84, 98-110.

Kelly, D. D. (New York State Psychiat. Inst., Dept. of Behav. Physiol., 722 W. 168th St., New York, N.Y. 10032 ). Long-term prereward suppression in monkeys unaccompanied by cardiovascular conditioning. Journal of the Experimental Analysis of Behavior, 1973, 20, 93-104.

Konzett, H. (Pharmakologisches Institut der Universität Innsbruck, Innsbruck, Austria), Berner, W., \& Lochs, H. Psychopharmacologia (Berl.), 1973, 30, 75-82.

Lieblich, I. (Hebrew Univ. of Jerusalem, Jerusalem, Israel), Kugelmass, S., \& Ben-Shakhar, G. Psychophysiological baselines as a function of race and ethnic origin. Psychophysiology, 1973, 10, 426-430.

Mandel, I. J. (Dept. of Psychiat., Albert Einstein Coll. of Med., Yeshiva Univ., Bronx, N.Y. 10461), \& Bridger, W. H. Cross-modality transfer of differential galvanic skin response conditioning to word stimuli. Journal of Experimental Psychology, 1973, 99, 157-161.

Simpson, D. D. (Inst. of Behav. Rsch., Texas Christian Univ., Ft. Worth, Tex. 76129). Patterns of respiratory behavior. Physiological Psychology, 1973, 1, 141-146.

Sroufe, L. A. (Inst. of Child Devel., Univ. of Minnesota, Minneapolis, Minn. 55455), \& Morris, D. Respiratory-cardiac relationships in children. Psychophysiology, 1973, 10, 377-382. 